\title{
1 Pigment composition and photoprotection of Arctic sea ice algae during \\ 2 spring
}

3

4

5

6

7

\author{
Virginie Galindo ${ }^{1, *}$, Michel Gosselin², Johann Lavaud ${ }^{3}$, C. J. Mundy ${ }^{1}$, Brent Else ${ }^{4}$, Jens Ehn ${ }^{1}$, \\ Marcel Babin ${ }^{3}$, Søren Rysgaard ${ }^{1,5,6}$
}

${ }^{1}$ Centre for Earth Observation Science, Faculty of Environment, Earth and Resources, University of Manitoba, Winnipeg, Manitoba R3T 2N2, Canada

${ }^{2}$ Institut des sciences de la mer de Rimouski, Université du Québec à Rimouski, Rimouski, Québec G5L 3A1, Canada

${ }^{3}$ UMI 3376 TAKUVIK, Département de biologie, CNRS/Université Laval, Québec-Océan, Québec, Québec G1V 0A6, Canada

${ }^{4}$ Department of Geography, University of Calgary, Calgary, Alberta T2N 1N4, Canada

${ }^{5}$ Arctic Research Centre, Aarhus University, 8000 Aarhus, Denmark

${ }^{6}$ Greenland Climate Research Centre, Greenland Institute of Natural Resources, PO Box 570, 3900 Nuuk, Greenland

*Corresponding author: virginie.galindo@gmail.com

RPH: Galindo et al.: Photoprotection of bottom Arctic ice algae

ABSTRACT: From the beginning of spring to the melt period, ice algae in the bottom of Arctic sea ice experience a large irradiance range, varying from $<0.1 \%$ up to 25 or $30 \%$ of the incoming visible radiation. The increase in spring is usually rapid, with a varying photoacclimative response by bottom ice algae to protect themselves against excess light, such as changes in cellular pigment composition. This study focused on the temporal variation in pigment composition of bottom ice algae under 2 contrasting snow depths (thin and thick) during spring. 
Controlled experiments were also carried out to investigate the photoprotective capacity of ice algae to relatively high irradiances during a short-term period $(<6 \mathrm{~h})$. Bottom ice algae were able to photoacclimate rapidly and effectively to irradiance ranging from 10 to $100 \mu \mathrm{mol}$ photons $\mathrm{m}^{-2}$ $\mathrm{s}^{-1}$. However, we observed contrasting responses in photoacclimation depending on the ice algal community composition and their light history. Our experimental results suggest that the xanthophyll cycle (diadinoxanthin to diatoxanthin conversion) and D1-protein recycling play an important role in stabilizing photoprotection in ice algae. In addition, bottom ice algae likely employed a 'cellular light-exposure memory' strategy in order to improve their photoacclimative response to changing light exposure. According to our data, this process could be maintained over at least $2 \mathrm{wk}$. Hence, ice algae may be more resilient to varying light conditions than previously thought, and may be well-adapted for the expected future light regime changes associated with variability in snow and sea ice cover.

KEY WORDS: Arctic $\cdot$ Snow melt $\cdot$ Ice algae $\cdot$ Pigments $\cdot$ Photoacclimation $\cdot$ Light memory

\section{INTRODUCTION}

The ice algal community resides mostly in the bottom $10 \mathrm{~cm}$ of sea ice (Smith et al. 1990, Riedel et al. 2008, Juhl et al. 2011) and is largely dominated by diatoms (Poulin et al. 2011), a very abundant and productive group of unicellular algae (Malviya et al. 2016). Diatoms are successfully adapted to polar conditions due to their unique low-light acclimation (Petrou et al. 2016, Lacour et al. 2017). Ice algae represent the initial and most significant source of primary production during the winter-spring transition in Arctic waters. They contribute 5-20\% of total marine primary production in Arctic seasonally ice-covered waters (e.g. Michel et al. 2006, Arrigo et al. 2010, Loose et al. 2011) and $>50 \%$ in perennially ice-covered waters (Legendre et al. 1992, Gosselin et al. 1997). Primary production of ice algae is influenced by many environmental variables such as temperature (Arrigo \& Sullivan 1992), salinity (Ryan et al. 2004), and nutrient availability (Lizotte \& Sullivan 1992, Lavoie et al. 2005), but mainly by irradiance in the range of photosynthetically active radiation ( $E_{\mathrm{PAR}} ; 400$ to $700 \mathrm{~nm}$ ), which is principally regulated by the thickness of snow and ice cover (Mundy et al. 2005, Aumack \& Juhl 2015 ) in addition to the annual cycle and cloudiness. EPAR reaching the bottom of first-year sea ice is often $<1 \%$ of incident irradiance (Arrigo et al. 1993, Lazzara et al. 2007) at the beginning of spring, and thus the ice algal community is adapted to perform photosynthesis under very low 
irradiance (e.g. Cota 1985, Johnsen \& Hegseth 1991, Kühl et al. 2001). However, the rapid increase in light intensity and day length from winter to the spring melt period (Sakshaug \& Slagstad 1991) results in a rapid increase in EPAR of up to 25 or $30 \%$ of incident irradiance at the bottom ice (Perovich 2005, Campbell et al. 2014), exposing the ice algae to a large range of EPAR. Light conditions can also change rapidly on a daily basis, mainly due to opposite and/or cumulative effects of melting and storms (rain or snow) that modify the snow cover thickness and optical properties. Furthermore, the acceleration of global warming in the Arctic affects snow and sea ice cover. Snow cover declined by 40\% between 1989 and 2009 (Screen \& Simmonds 2012, Overland et al. 2014) and during some periods, precipitation has switched from snow to rain (Comiso \& Hall 2014), while sea-ice extent has retreated by $45 \%$ in the last 3 decades (Screen et al. 2011, Stroeve et al. 2012). All of these changes, accompanied by an earlier melt onset (Markus et al. 2009), are expected to increase the EPAR levels transmitted through the sea-ice cover. This increase in transmitted EPAR is foreseen to enhance ice algal biomass (Poulin et al. 2011) and production (Wassmann et al. 2011), but ice algae may also face light stress (Leu et al. 2016, Petrou et al. 2016) which may be of importance since they are adapted to very low light levels.

In order to sustain photosynthesis under changing light conditions, ice algae use some photobehavioral (i.e. vertical migration in pennate diatoms; Aumack et al. 2014) and photophysiological features described as photoprotection and photoacclimation. These photoprotective mechanisms allow algae to minimize oxidative photodamage generated by excess light exposure, and specifically to maintain photosystem II (PSII) photochemistry. They include changes in cellular photosynthetic and photoprotective pigment composition (Alou-Font et al. 2013), with an increase in antioxidant carotenes and xanthophylls depending on incident irradiance. On shorter time scales (i.e. $<1$ h) of light fluctuations, the most important photoprotective processes are the repair of damaged PSII (Petrou et al. 2010) and thermal dissipation of excess energy (Goss \& Lepetit 2015). This process comprises a fast (seconds to minutes) enzymatic light-driven conversion of xanthophyll cycle (XC) pigments (Goss \& Jakob 2010). In diatoms, the $\mathrm{XC}$ consists of the de-epoxidation of diadinoxanthin (DD) to diatoxanthin (DT) (Brunet et al. 2011, Kuczynska et al. 2015). In polar conditions, the XC is very important for optimizing algal photosynthetic activity during the spring-summer transition when 
transmitted irradiance at the ice-water interface increases (Kashino et al. 2002, Katayama \& Taguchi 2013, Ha et al. 2016, Katayama et al. 2017).

As bottom ice algae strongly contribute to Arctic marine primary production during spring, several studies have described their photophysiological responses to a change in $E_{\text {PAR }}$ levels from winter to spring (e.g. Gosselin et al. 1985, Barlow et al. 1988, Kudoh et al. 1997, Manes \& Gradinger 2009), through the spring season (e.g. Michel et al. 1988, Cota \& Horne 1989, Ban et al. 2006, Alou-Font et al. 2013) and from spring to summer (Rysgaard et al. 2001), with a special focus on the potential deleterious effects of ultraviolet radiation (UVR) (Enberg et al. 2015, Leu et al. 2016). A few works have also focused on the impact of change in snow cover on the photoacclimation of ice algae (Juhl \& Krembs 2010, Lund-Hansen et al. 2014), but little is known about their capacity to acclimate to rapid light changes through pigment photoprotection (Kudoh et al. 2003, Katayama \&Taguchi 2013, Petrou et al. 2016). Therefore, the main objectives of this study were to (1) determine the change in pigment composition including XC pigments related to the photoprotective response of the bottom ice algal community under 2 dominant snow depths (thin and thick) from the beginning of spring to early summer, and (2) investigate the short-term photoacclimation response to an experimental light gradient of bottom ice algae acclimated to 2 snow cover sites.

\section{MATERIALS AND METHODS}

\section{Study site, sample collection and experiments}

The study was conducted on landfast first-year sea ice, located north of Davis Strait near Qikiqtarjuaq, Nunavut, Canada (67 $28^{\prime} \mathrm{N}, 63^{\circ} 47^{\prime} \mathrm{W}$; Fig. 1), as part of the Green-Edge project. Sea ice samples were collected for measurements of pigments every 2 d from 27 April to 6 July 2015.

For the time series, ice sampling was performed at thick $(>25 \mathrm{~cm})$ and thin $(15$ to $20 \mathrm{~cm}$ less than thick snow) snow depths. Snow depth and ice thickness were measured on each ice sampling day with a ruler and an ice thickness gauge (Kovacs Enterprises), respectively. Transmittance of EPAR at the ice-water interface was also measured on each sampling day (see details below). The bottom $3 \mathrm{~cm}$ sections were extracted from sea-ice cores using a $14 \mathrm{~cm}$ internal diameter ice corer (Mark V Coring System; Kovacs Enterprises). For pigment analysis, 
at least 2 ice cores were extracted per snow site and pooled immediately in a dark isothermal container to avoid brine drainage losses. These ice core samples were melted in $0.2 \mu \mathrm{m}$ filtered seawater (FSW) (3 parts FSW to 1 part melted ice) to minimize osmotic stress on the microbial community during melting (Bates \& Cota 1986, Garrison \& Buck 1986). Ice-water interface samples for salinity and nutrient determination were collected through an auger hole with a battery-operated plastic submersible pump (Cyclone $\left.{ }^{\circledR}\right)$ secured to the end of an articulated under-ice arm.

Three distinct types of experiments with ice algae were carried out on 11 occasions between 6 and 31 May 2015 (Tale 1). For these experiments, the bottommost $1 \mathrm{~cm}$ of 3 sea-ice cores were quickly scraped (McMinn et al. 2005, 2010) and pooled in a dark isothermal container with $0.2 \mu \mathrm{m}$ FSW (ca. 38 parts FSW to 1 part melted ice) in order to reduce the time of melting, which can impact physiological processes. Indeed, too long of a dark period during the ice melting could result in DT to DD de-epoxidation (Goss \& Jakob 2010). In our study, ice samples were melted in less than $30 \mathrm{~min}$. The melted ice was gently mixed, and nutrients were sampled before the water was distributed into clear polycarbonate bottles under dim light conditions (i.e. diffusive light in a Polarhaven shelter with opaque walls and 2 end windows covered by 4 layers of black plastic sheeting).

During the first experiment (Table 1), three $500 \mathrm{ml}$ polycarbonate bottles (EPAR transmittance of ca. 80\%) containing ice melt water were placed in each experimental chamber. Each chamber was then exposed to one light intensity $\left(10,50,100\right.$ or $200 \mu \mathrm{mol}$ photons $\left.\mathrm{m}^{-2} \mathrm{~s}^{-1}\right)$ using cool white dimmable LEDS (9 W) and neutral density light filters (LEE Filters). During the experimental period, irradiance at the ice-water interface ranged from 0.3 to $8 \mu \mathrm{mol}$ photons $\mathrm{m}^{-2} \mathrm{~s}^{-1}$, and therefore ice algae were acclimated to different light levels in their natural environment. The experimental chambers were continuously cooled with running seawater pumped from the ice-water interface using a small electric submersible pump (Lifegard Aquatics QuietOne Model 1200, 317 GPH). The ice algae were exposed to their respective treatments for $3 \mathrm{~h}$ and then placed at the lowest light levels achievable in the field $\left(<5 \mu \mathrm{mol}\right.$ photons $\mathrm{m}^{-2} \mathrm{~s}^{-1}$, incubators covered by 4 layers of black plastic sheeting) for a $2 \mathrm{~h}$ dark-recovery period. The same experiment was repeated on 7 occasions and the data from the same ice algae (from thin or thick snow) and the same period (before or during snowfall) were averaged. Subsampling for 
pulse-amplitude modulation (PAM) fluorometry measurements (i.e. chlorophyll $a$ [chl $a$ ] fluorescence) occurred at $0,0.5,1,2,3$ and $5 \mathrm{~h}$, while pigment composition was assessed at 0,3 and $5 \mathrm{~h}$.

In the second experiment (Table 1), the relative importance of photoprotection and photorepair mechanisms were assessed using 2 inhibitors: dithiothreitol (DTT) and lincomycin. The xanthophyll inhibitor DTT prevents the de-epoxidation of DD into DT (Olaizola et al. 1994, Lavaud et al. 2002) whereas lincomycin prevents the transcription of chloroplast-encoded D1 proteins (psbA) and therefore inhibits the repair of photodamaged PSII (Petrou et al. 2010). Duplicate $500 \mathrm{ml}$ polycarbonate bottles containing melted ice water from a thin snow cover site were prepared (1) without inhibitor (i.e. control), (2) with DTT (final concentration $100 \mu \mathrm{mol} \mathrm{1}{ }^{-1}$; Olaizola et al. 1994) and (3) with lincomycin (final concentration $600 \mu \mathrm{mol} \mathrm{l}^{-1}$; Kropuenske et al. 2009). Approximately $5 \mathrm{~min}$ after adding the chemical, the bottles were incubated for $6 \mathrm{~h}$ at the ice-water interface using a custom-built under-ice arm. Subsamples for PAM fluorescence and pigment analysis were collected every $2 \mathrm{~h}$ between 11:00 and 17:00 h (local time; UTC 05:00).

In the third experiment (Table 1), duplicate 21 polycarbonate bottles containing melted ice water from both snow covers were incubated in an opaque-walled incubator located on the snow, exposed to incident irradiance (EPAR + UVR) and continuously cooled with running seawater pumped from the ice--water interface using a small electric submersible pump (Pondmaster magnetic drive utility pump, Model 500 GPH). Subsamples were collected for PAM fluorescence and pigment analysis after $30 \mathrm{~min}$ and every hour thereafter for $3 \mathrm{~h}$.

\section{Irradiance measurement}

During the study period, transmitted irradiance was measured every sampling day between 10:00 and 11:00 h (local time; UTC - 05:00) using a compact-optical profiling system (C-OPS; Biospherical Instruments). Incident and under-ice downward irradiances were recorded at 19 individual wavelengths (from 320 to $780 \mathrm{~nm}$ ) by a cosine light sensor. The vertical profile of irradiance under the sea ice was measured by the IcePRO version of the instrument, which is specifically design to fit and sink through a $25 \mathrm{~cm}$ diameter ice auger hole. EPAR was computed by constructing a piecewise cubic hermit interpolating polynomial (PCHIP) using downward 
irradiance measured at all C-OPS wavelengths and then numerically integrating from 400 to 700 $\mathrm{nm}$ to obtain final units of $\mu \mathrm{mol}$ photons $\mathrm{m}^{-2} \mathrm{~s}^{-1}$ (Mobley 1994). The transmitted irradiance at the ice-water interface was calculated as detailed in Belzile et al. (2000). The water column diffuse attenuation coefficient was determined from the linear portion of triplicate measurements of the natural logarithm of the transmitted irradiance versus depth. Due to the alteration of light profiles underneath the ice because of the auger hole and the snow added on it, the EPAR plots were linear, on average, from 10 to $50 \mathrm{~m}$. The $\mathrm{r}^{2}$ of the relationship between the natural logarithm of the transmitted irradiance versus depth was always $>0.99$.

To estimate incident irradiance and $E_{\mathrm{PAR}}$ at the ice-water interface over a day, we used incident downward shortwave (305 to $2800 \mathrm{~nm}$ ) radiation, which was measured continuously (as 1 min averages). The shortwave radiation measurements were made using the upward-looking cosine response pyranometer on a 4-sensor net radiometer (Kipp \& Zonen; model CNR4) placed at an undisturbed site approximately $20 \mathrm{~m}$ west of the meteorological station at a height of $1 \mathrm{~m}$ above the snow. The instrument included a heater/ventilator unit (Kipp \& Zonen; model CNF4) that cycled on for $5 \mathrm{~min}$ at the beginning of every hour to keep the instrument lenses free of snow and frost. We noticed that the heater/ventilator caused a transient increase in measured shortwave radiation under certain atmospheric conditions (light winds, clear skies). In these cases, we used a smoothing algorithm to remove minor data spikes. Incident downward shortwave radiation was converted to $E_{\text {PAR }}$ (multiplied by 0.47 ) as described by Papaioannou et al. (1993). Then the $E_{\mathrm{PAR}}$ value in $\mathrm{W} \mathrm{m}^{-2}$ was converted into $\mu \mathrm{mol}$ photons $\mathrm{m}^{-2} \mathrm{~s}^{-1}$ using a factor of 4.15 as described in Halverson \& Pawlowicz (2013). As algae act as scalar collectors with a maximum interception of light incident from all directions due to the arrangement of their photosynthetic tissues, scalar irradiance is the preferred measurement (Kirk 2011). To calculate scalar irradiance at the ice-water interface, we first estimated downward irradiance at the icewater interface by multiplying the incident downwelling EPAR on the surface by the calculated EPAR transmittance (as detailed above). This subsequent downward irradiance was converted to downward scalar irradiance by dividing by an average cosine factor of 0.7 (Ehn \& Mundy 2013). To simplify, we assumed that the upward scalar irradiance was negligible at the ice-water interface. Due to this assumption, we note that our scalar irradiance estimates are likely conservative. Although no direct measurements have been reported, the modeling study of 
Pavlov et al. (2017) estimated scalar irradiance at the ice bottom to be $\sim 1.8$ times greater than EPAR, in comparison to our estimate that was scaled by a factor of 1.4.

\section{Salinity and nutrients}

Salinity of melted ice samples was measured with a hand-held conductivity meter (330i/SET; WTW) calibrated against a $15 \mathrm{~N} \mathrm{KCl}$ solution at $20^{\circ} \mathrm{C}$. Samples for nutrient determination at the ice-water interface and in the experiments were filtered through a precombusted $\left(5 \mathrm{~h}\right.$ at $450^{\circ} \mathrm{C}$ ) Whatman $\mathrm{GF} / \mathrm{F}$ glass-fiber filter (nominal porosity of $0.7 \mu \mathrm{m}$ ) inserted in a filter holder. The filtrate was collected into $20 \mathrm{ml}$ polyethylene vials after thorough rinsing. Samples were poisoned with mercuric chloride (final concentration $10 \mu \mathrm{g} \mathrm{ml}^{-1}$ ) according to Kirkwood (1992), and stored in the refrigerator until analysis. Nitrate plus nitrite (hereinafter NOx), nitrite, phosphate and silicic acid were analyzed using a Bran Luebbe Seal autoanalyzer according to the method of Aminot \& Kérouel (2007). The analytical detection limits for NOx, phosphate and silicic acid were $0.05,0.02$ and $0.2 \mu \mathrm{mol}^{-1}$, respectively.

\section{Chl $a$ variable fluorescence}

To study the photosynthetic responses of algae, PAM fluorometry was used. It is a widely used methodology that provides a rapid, non-invasive assessment of the photosynthetic apparatus of algal cells (Parkhill et al. 2001). It is also a useful tool to examine the ability of photosynthetic organisms to tolerate environmental stressors and the extent of damage caused by these stresses (Maxwell \& Johnson 2000). Fluorescence measurements were made with a water-PAM cuvette version with blue LEDs (Walz) inside the unheated field laboratory (Polarhaven shelter), which was set up at the sampling station. All samples were placed in a small cooler containing 2 ice packs during their dark-acclimation for at least $30 \mathrm{~min}$ before the measurement of fluorescence. The samples were stirred during measurements.

Minimum $\left(F_{0}\right)$ and maximum fluorescence $\left(F_{\mathrm{m}}\right)$ levels were assessed, and the maximum quantum yield of PSII photochemistry $\left(F_{\mathrm{v}} / F_{\mathrm{m}}\right)$ was calculated as follows:

$$
F_{\mathrm{v}} / F_{\mathrm{m}}=\left(F_{\mathrm{m}}-F_{0}\right) / F_{\mathrm{m}}
$$

$F_{\mathrm{m}}$ was obtained using a saturating pulse of ca. $3000 \mu \mathrm{mol}$ photons $\mathrm{m}^{-2} \mathrm{~s}^{-1}$ for $0.8 \mathrm{~s}$. When measured on a community, $F_{\mathrm{v}} / F_{\mathrm{m}}$ changes must be interpreted with care (see, for example, 
Parésys et al. 2005). Nevertheless, in our study, sea-ice algae communities were largely dominated by diatoms (see 'Results'). Hence, $F_{\mathrm{v}} / F_{\mathrm{m}}$ variations can be largely attributed to changes in the photosynthetic efficiency of diatoms.

Rapid light curves (RLCs) were also generated to determine the photosynthetic parameters under both snow covers as a function of snow conditions (before or during snow events). Dark-acclimated samples were exposed to successive increasing actinic light ranging from 0 to $139 \mu \mathrm{mol}$ photons $\mathrm{m}^{-2} \mathrm{~s}^{-1}$ for $30 \mathrm{~s}$ each. The actinic light was measured with a spherical micro quantum sensor US-SQS (Walz). The relative electron transport rate (rETR; dimensionless) values were calculated as follows:

$$
\mathrm{rETR}=\varphi \text { PSII } \times E
$$

where $\varphi$ PSII $=\left(F_{\mathrm{m}}{ }^{\prime}-F^{\prime}\right) / F_{\mathrm{m}}{ }^{\prime}$, known as the operational PSII quantum yield and $E$ is the irradiance applied.

Data from RLCs were fitted using the following equation (Eilers \& Peeters 1988, Zonneveld 1998) using a Levenberg-Marquardt regression algorithm:

$$
\mathrm{rETR}=E /\left(a E^{2}+b E+c\right)
$$

where $E$ is irradiance, and $a, b$ and $c$ are regression coefficients to fit the rETR versus $E$ curve. RLC measurements allow us to describe the main photosynthetic properties of an algal sample, including the maximum ( rETR $\left._{\max }\right)$, the light use efficiency $(\alpha)$ represented by the initial slope of the curve ( $\mu \mathrm{mol}$ photons $\left.\mathrm{m}^{-2} \mathrm{~s}^{-1}\right)^{-1}$ and the light saturation coefficient $\left(E_{k} ; \mu \mathrm{mol}\right.$ photons $\left.\mathrm{m}^{-2} \mathrm{~s}^{-1}\right)$ (Ryan et al. 2009) using the following expressions:

$$
\begin{gathered}
\alpha=1 / c \\
\mathrm{rETR}_{\text {max }}=\left[b+2(a c)^{0.5}\right]^{-1} \\
E_{k}=\mathrm{rETR}_{\max } / \alpha
\end{gathered}
$$

As for typical ${ }^{14} \mathrm{C} P-E$ curves, these photosynthetic parameters were used to compare the photosynthetic performances and photoacclimation properties of algal communities.

\section{Pigments and CHEMTAX analysis}


The identification and concentration of algal pigments were determined by reverse-phase HPLC. Samples (50 to $200 \mathrm{ml}$, depending on the biomass) were filtered onto $25 \mathrm{~mm}$ Whatman $\mathrm{GF} / \mathrm{F}$ filters using a vacuum pump $(0.8 \mathrm{~mm} \mathrm{Hg})$, wrapped in aluminum foil and stored immediately at $-80^{\circ} \mathrm{C}$ until analysis. For the time series, the algal pigments of the bottom $3 \mathrm{~cm}$ of the ice were extracted at $-20^{\circ} \mathrm{C}$ in $3 \mathrm{ml} 100 \%$ methanol, disrupted by $10 \mathrm{~s}$ of sonication (Bandelin Sonopuls HD2200) and filtered $1 \mathrm{~h}$ later through $25 \mathrm{~mm}$ Whatman GF/F filters. The pigments were separated and quantified as described in Ras et al. (2008), a method adapted from Van Heukelem \& Thomas (2001). Pigments were analyzed using an Agilent Technologies 1200 Series system with a narrow reversed-phase C8 Zorbax Eclipse XDB column $(150 \times 3 \mathrm{~mm}, 3.5$ $\mu \mathrm{m}$ particle size) which was maintained at $60^{\circ} \mathrm{C}$. A diode-array detector allowed measuring the absorption of most pigments at $450 \mathrm{~nm}$, while chl $a$ and its derivatives were detected at $667 \mathrm{~nm}$. For the light experiments, the algal pigments were extracted as described in Alou-Font et al. (2013, 2016) and disrupted by $10 \mathrm{~s}$ of sonication (Heat Systems; model XL2010). The remaining pigment samples were analyzed using an Agilent Technologies 1200 Series but with a Symmetry C8 column $(150 \times 4.6 \mathrm{~mm}, 3.5 \mu \mathrm{m}$ particle size; Waters Corporation). Pigments were detected with a G1315P diode-array absorbance detector (400 to $700 \mathrm{~nm}$ ) and chlorophylls were detected by fluorescence (excitation at $400 \mathrm{~nm}$ and emission at $650 \mathrm{~nm}$; G1321A fluorescence detector). We used the HPLC separation method described in Zapata et al. (2000). For both methods, pigments were identified based on retention time and spectral properties of external pigment standards, even for degradation pigments (chlorophyllide $a$, pheophytin $a$, pheophorbide $a$ ) (DHI Lab Products) (Egeland et al. 2011). Limits of detection and quantification were estimated as in Bidigare et al. (2005) and pigments with concentrations below the limit of detection were not reported. In this study, total $\operatorname{chl} a(\mathrm{Tchl} a)$ mentioned thereafter corresponds to the sum of $\operatorname{chl} a$, chlorophyllide $a$, chl $a$ allomer and epimer measured by HPLC. The ratios of photoprotective carotenoids (PPC; including DD, DT, violaxanthin, zeaxanthin and $\beta, \beta$-carotene) to photosynthetic carotenoids (PSC; including fucoxanthin, peridinin, 9'-cis-neoxanthin and alloxanthin) were also calculated. The de-epoxidation state (DES) index, an indicator of photoprotection (Barnett et al. 2015), was expressed as DES = DT / (DD + DT) and calculated for the different experiments.

The contribution of major algal groups to chl $a$ was determined from marker pigment ratios using the CHEMical TAXonomy (CHEMTAX) program (Mackey et al. 1996, version 1.95 
as used in Wright et al. 2009). According to Mackey et al. (1996), the accuracy of CHEMTAX calculations is optimized when calculations are done on smaller groups of samples, with stable pigment ratios. Thus, samples were separated into 4 data sets with similar environmental (snow depth) and biological (algal bloom phase) conditions. CHEMTAX was used separately on each data set, and the average was calculated for each condition. As the data sets were separated in the same way as those in Alou-Font et al. (2013), we used the same initial pigment ratio matrices defined therein. Therefore, to improve biomass estimation, 10 successive runs of CHEMTAX using the output from each run as the input for the next was used, as recommended by Latasa (2007) and used in recent studies (e.g. Eker-Develi et al. 2012, Liu et al. 2012, Wang et al. 2015). The final ratio matrices are displayed in Table S1 in the Supplement at www.intres.com/articles/suppl/mXXXpXXX_supp.pdf.

\section{Statistical analysis}

Normality of the data was determined using the Shapiro-Wilk test with a 0.05 significance level. When the data were normally distributed, we used parametric tests. For the time series and the third experiment, paired $t$-tests were used to compare paired variables from the thin and thick snow cover sites. For non-parametric data, a Wilcoxon signed rank test was used instead. To determine differences among the 3 sampling periods, a 1-way ANOVA by ranks (Kruskal-Wallis test) was performed and completed by a multiple mean comparison test using rank sums (Dunn's test) adjusted with the Bonferroni method. In addition, Pearson's linear correlations (r) on parametric data were used to infer the relationship between 2 variables. For the first experiment, 1-way repeated ANOVA was performed followed by a post hoc Tukey's test to identify averages that were significantly different between treatments. A $t$-test was also conducted to determine the difference in algal responses (e.g. decline) depending on snow cover. The $t$-statistic, df and p-values are provided in brackets when reported. Statistical tests and graphics were produced with SigmaPlot v.12.3 (Systat Software) and R (R Development Core team 2009).

\section{RESULTS}

\section{Change in environmental conditions}


Because of temporal changes in snow cover depth resulting from major snow precipitation events on 16 and 20 May, we distinguish 3 sampling periods (i.e. before and during snow events, and snowmelt; $\mathbb{E} i g .2$ ). Snow depth remained relatively stable at both sites until 12 May, and increased from ca. 10 to $30 \mathrm{~cm}$ and from ca. 25 to $51 \mathrm{~cm}$ on 20 May at thin and thick snow cover sites, respectively (Fig. 2a). Thereafter, snow depth slowly decreased at both sites until 9 June, when it decreased faster until reaching $0 \mathrm{~cm}$ on 20 June at the thin snow site and later at the thick snow site. Mean sea-ice thickness ranged from 132 to $96 \mathrm{~cm}$ during the sampling season (Fig. 2b) and was significantly thinner during the melting period (mean $=116$ $\mathrm{cm})$ than during the 2 previous periods (mean $=124 \mathrm{~cm})($ Dunn's test, $\mathrm{p}<0.05)$.

Nutrient concentrations at the ice-water interface varied from 5.38 to $1.38 \mu \mathrm{mol}^{-1}$ for $\mathrm{NO}$ (Fig. 2c), from 0.22 to $0.04 \mu \mathrm{mol}^{-1}$ for $\mathrm{NO}_{2}{ }^{-}$, from 7.4 to $5.5 \mu \mathrm{mol} \mathrm{l}^{-1}$ for $\mathrm{Si}(\mathrm{OH})_{4}$ and from 0.92 to $0.60 \mu \mathrm{mol} 1^{-1}$ for $\mathrm{PO}_{4}{ }^{3-}$. NOx concentrations oscillated between 4.21 and $5.38 \mu \mathrm{mol}$ $1^{-1}$ from the beginning of the sampling period until 10 June and then started to decrease progressively down to $1.38 \mu \mathrm{mol}^{-1}$ at the end of sampling (Fig. 2c). Mean concentrations of $\mathrm{NO}, \mathrm{Si}(\mathrm{OH})_{4}$ and $\mathrm{PO}_{4}{ }^{3-}$ were significantly lower during the melting period (after 10 June) than during the 2 previous periods (Dunn's test, $\mathrm{p}<0.05$ ).

EPAR transmittance through the ice and snow remained relatively constant at around $0.06 \%$ of incident irradiance until 31 May and then increased progressively up to $4.6 \%$ on 6 July due to the complete snowmelt (Fig. 2d). Mean EPAR transmittance was significantly higher after 9 June than before this date (Dunn's test, $\mathrm{p}<0.05$ ).

\section{Effect of snow events and snow cover depth on ice algal biomass, pigment composition and photosynthetic properties}

During the first sampling period (i.e. before snow events), bottom ice Tchl $a$ concentration, used as an index of ice algal biomass, was significantly higher under the thin snow $\left(9.28 \mathrm{mg} \mathrm{m}^{-2}\right)$ than under the thick snow $\left(5.14 \mathrm{mg} \mathrm{m}^{-2}\right)$ cover (paired $t$-test, $t=3.632, \mathrm{df}=$ $11, \mathrm{p}<0.01$ ) (Fig. 3a). During the following 2 periods (i.e. snow events and snowmelt), no significant difference in algal biomass was observed between the 2 snow cover conditions (paired $t$-test, $t=1.556, \mathrm{df}=9, \mathrm{p}=0.15$ during snow events and $t=0.566, \mathrm{df}=4, \mathrm{p}=0.60$ during snowmelt). During the snow events period, bottom ice Tchl $a$ concentration reached a 
maximum value of $22 \mathrm{mg} \mathrm{m}^{-2}$ on 27 May and $32 \mathrm{mg} \mathrm{m}^{-2}$ on 2 June at the thick and thin snow sites, respectively. Thereafter, Tchl $a$ concentrations decreased progressively to reach a minimum value of $0.18 \mathrm{mg} \mathrm{m}^{-2}$ at the thick snow site during the snowmelt period. No samples were collected at the thin snow site after 24 June.

The concentrations of PSC and PPC followed the same trend as Tchl $a$. PSC variations were mainly influenced by fucoxanthin, while PPC were mostly governed by DD and $\beta, \beta-$ carotene. The PPC:PSC ratio was relatively constant before and during snow events, with values around $0.1 \mathrm{wt}: \mathrm{wt}$, followed by an increase up to $0.81 \mathrm{wt}$ :wt during the snowmelt period (Fig. $3 b$ ). Before snow events, the PPC:PSC ratio was significantly higher under thin snow (0.12 wt:wt) than under thick snow (0.09 wt:wt) (paired $t$-test, $t=2.393, \mathrm{df}=11, \mathrm{p}<0.05)$. This ratio was positively correlated with EPAR transmittance at the ice-water interface under both thin $(\mathrm{r}=$ $0.816, \mathrm{p}<0.001)$ and thick snow covers $(\mathrm{r}=0.828, \mathrm{p}<0.001)$ and during the snowmelt period $(\mathrm{r}$ $=0.812, \mathrm{p}<0.001)$. Over the entire sampling period, the ratio of (DD+DT) to Tchl $a$ followed the same trend as PPC:PSC (Fig. 3b,c). (DD+DT):Tchl $a$ was stable around $0.03 \mathrm{wt}$ :wt before and during snow events and increased to $0.28 \mathrm{wt}$ :wt during the snowmelt period under both snow cover conditions. It was significantly higher under thin snow (0.04 wt:wt) than under thick snow (0.02 wt:wt) cover before snow events (paired $t$-test, $t=3.460, \mathrm{df}=11, \mathrm{p}<0.01)$ and was positively correlated with ice bottom EPAR transmittance during the snowmelt period $(\mathrm{r}=0.667$, $\mathrm{p}<0.05)$.

The contributions of major algal groups to chl $a$ were determined via CHEMTAX analysis, which showed that diatoms were always dominant under both snow covers during the entire sampling period ( $>82 \%$; 18 .4). Diatoms Type 2, containing fucoxanthin and chl $c 2$ and C3, were likely associated with pennate diatoms in Alou-Font et al. (2013), while diatoms Type 1 were associated with centric diatoms. Some differences occurred depending on the snow cover and snow periods. Before snow events, diatoms Type 2 (i.e. pennate diatoms) totally dominated under the thin snow cover, while the algal community was more heterogeneous under thick snow with the presence of diatoms Type 1 (16\%), cryptophytes (14\%) and dinoflagellates (3\%). Thereafter, during snow events, the algal community was more heterogeneous under both snow covers, but dinoflagellates $(3 \%)$ and cryptophytes $(2 \%)$ were relatively more abundant under thin snow cover. Finally, diatoms entirely dominated the algal community during the snowmelt 
period (ca. 99\%) with a dominance of diatoms Type 1 (i.e. centric diatoms), but diatoms Type 2 (i.e. pennate diatoms) were 4 times more abundant under thick snow cover (20 vs. 5\%). Hence, despite the dominance of diatoms in all samples, some differences in algal community (heterogeneous or diatom types) occurred depending on the environmental conditions.

Before the period of snow events, there was a clear difference in photosynthetic properties and photoacclimation in ice algae living under thin or thick snow cover (Table 2). As expected, $\alpha$ was lower and $\mathrm{rETR}_{\max }$ was higher under thin snow. As a result, $E_{k}$ was twice as high (ca. $45 \mu \mathrm{mol}$ photons $\mathrm{m}^{-2} \mathrm{~s}^{-1}$ ) under thin snow. During the snow event period, ice algae under the thin snow cover maintained rETR $_{\max }$ and increased $\alpha$ resulting in a $E_{k}$ decrease of half, reaching a value similar to that under the thick snow cover before the snow event period. Interestingly, ice algae under thick snow cover maintained $\alpha$ (probably because it was already at its maximum), yet increased rETR $_{\max }$ to a similar level as ice algae under thin snow cover during snow events.

\section{Effect of a natural range of light exposure on the photophysiology of bottom ice algae as a function of snow conditions}

Two types of experiments were performed to determine the short-term effect of enhanced irradiance on the photophysiological response of bottom ice algae (see Table 1). The aim of the first experiment was to assess the short-term effect of enhanced irradiance over a range typically observed at the ice-water interface (10 to $200 \mu \mathrm{mol}$ photons $\mathrm{m}^{-2} \mathrm{~s}^{-1}$; see Ryan et al. 2011, AlouFont et al. 2013) on the photophysiological response of bottom ice algae acclimated to different light environments depending on the snow conditions (i.e. snow depth and snow events). Before snow events, the $F_{\mathrm{v}} / F_{\mathrm{m}}$ ratio, a proxy for the maximum quantum yield for PSII photochemistry, was significantly lower after a $3 \mathrm{~h}$ light-exposure to the highest light treatment (i.e. $200 \mu \mathrm{mol}$ photons $\mathrm{m}^{-2} \mathrm{~s}^{-1}$ ) (1-way repeated ANOVAs completed by post hoc Tukey's tests, $q=4.644$ and $\mathrm{p}<0.05$ for thin snow, and $q=3.464$ and $\mathrm{p}<0.05$ for thick snow cover) $(\mathbb{i g}$. $5 \mathrm{a}, \mathrm{b})$. The decrease in $F_{\mathrm{v}} / F_{\mathrm{m}}$ was greater for thick snow ( $t$-test, $\left.t=24, \mathrm{p}<0.05\right)$. After $2 \mathrm{~h}$ of darkness, $F_{\mathrm{v}} / F_{\mathrm{m}}$ did not change. For the thin snow cover (Fig. 5a), the $F_{\mathrm{v}} / F_{\mathrm{m}}$ response was different with an increase throughout the light exposure and recovery period, especially for the 10 and $50 \mu \mathrm{mol}$ photons $\mathrm{m}^{-2} \mathrm{~s}^{-1}$ treatments, and it reached final values higher than those at $T_{0}(\mathrm{ca} .0 .55)$. For 
thick snow cover (Fig. 5b), $F_{\mathrm{v}} / F_{\mathrm{m}}$ strongly decreased during the first $30 \mathrm{~min}$ of illumination in light treatments of 10, 50 and $100 \mu \mathrm{mol}$ photons $\mathrm{m}^{-2} \mathrm{~s}^{-1}$, followed by stabilization and a recovery to $T_{0}$ values during dark recovery. During snow events (Fig. $5 \mathrm{c}, \mathrm{d}$ ), the $F_{\mathrm{v}} / F_{\mathrm{m}}$ decrease for thin snow cover was significantly different from those before snow events $(t$-test, $t=3.702, \mathrm{df}=7, \mathrm{p}$ $<0.01)$ at $200 \mu \mathrm{mol}$ photons $\mathrm{m}^{-2} \mathrm{~s}^{-1} . F_{\mathrm{v}} / F_{\mathrm{m}}$ reached the same minima after $3 \mathrm{~h}$ of light exposure (ca. 0.30 to 0.35 ). For lower light intensity treatments, $F_{\mathrm{v}} / F_{\mathrm{m}}$ was rather stable throughout the experiment, except for the $100 \mu \mathrm{mol}$ photons $\mathrm{m}^{-2} \mathrm{~s}^{-1}$ treatment for thick snow, which showed a stronger decrease and lower recovery than before snow events. Because $F_{\mathrm{v}} / F_{\mathrm{m}}$ is also influenced by nutrient availability in situ (Lin et al. 2016) as well as in experimental conditions (Parkhill et al. 2001), we verified that nutrient concentrations were not limiting in our incubation bottles (see Table S2 in the Supplement). Furthermore, due to low primary production (maxima ranged from

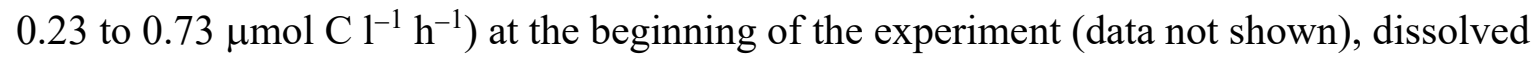
inorganic carbon concentrations (ca. $2105 \pm 9.12 \mu \mathrm{mol} \mathrm{kg}{ }^{-1}$ ) were sufficient to provide enough carbon for the photosynthesis of ice algae. In addition to $F_{\mathrm{v}} / F_{\mathrm{m}}$, DES (an index of DD de-

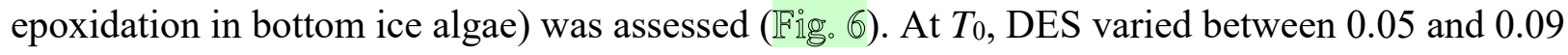
wt:wt and it increased significantly under the 2 highest light treatments (100 and $200 \mu \mathrm{mol}$ photons $\mathrm{m}^{-2} \mathrm{~s}^{-1}$ ) to a maximum level of 0.14 to $0.20 \mathrm{wt}$ :wt. While it was strongly positively correlated with the increase of $E_{\text {PAR }}$ at the ice-water interface $(r=0.85, p<0.001)$, no significant difference was observed before or during snow events or between snow covers (thin or thick). After $2 \mathrm{~h}$ of dark-recovery, DES decreased back to its $T_{0}$ values, independent of snow events and snow depth conditions.

In a second, complementary experiment, we aimed to determine the respective importance of DD de-epoxidation and of the synthesis of PSII D1 (psbA) protein to support bottom ice algae in maintaining their photochemical performance when exposed to their natural light environment. For that purpose, bottom ice algae were collected under thin snow cover and incubated at the ice-water interface in the absence (control) and presence of the inhibitor of DD de-epoxidation (i.e. DTT), and of D1 protein synthesis (i.e. lincomycin) ("ig。7). During the experiment, estimated ice bottom $E_{\mathrm{PAR}}$ transmittance progressively decreased from 105 to 53 $\mu \mathrm{mol}$ photons $\mathrm{m}^{-2} \mathrm{~s}^{-1}$ from 11:00 to 17:00 h local time (Fig. 7a), a range of irradiance encompassed by that of the first experiment. In all treatments, $F_{\mathrm{v}} / F_{\mathrm{m}}$ decreased during the first 4 
h (Fig. $7 b$; ca. -25 to $-30 \%)$ until reaching similar values at mid-afternoon $(15: 00 \mathrm{~h})$ and increased slightly thereafter concomitantly with the sharpest EPAR decrease (from 75 to $53 \mu \mathrm{mol}$ photons $\mathrm{m}^{-2} \mathrm{~s}^{-1}$ ). There was a greater $F_{\mathrm{v}} / F_{\mathrm{m}}$ decline after $2 \mathrm{~h}$ light exposure in the presence of DTT and lincomycin (ca. -20 to $-25 \%$ ) in comparison with the control conditions $(-5 \%)$. It is noteworthy that $F_{\mathrm{v}} / F_{\mathrm{m}}$ response in control conditions after $2 \mathrm{~h}$ light exposure was similar to the response observed in our controlled experimental light treatment (Expt 1, thin snow cover, 100 $\mu$ mol photons $\mathrm{m}^{-2} \mathrm{~s}^{-1}$; Fig. 5a). In control conditions, DES increased for the first $2 \mathrm{~h}$ from 0.063 to $0.086 \mathrm{wt}$ :wt and stabilized until $15: 00 \mathrm{~h}$, after which it decreased back to $T_{0}$ values, while EPAR at the ice-water interface reached its lowest values (Fig. 7a). In DTT-treated samples, DES was stable around its $T_{0}$ value. At $T_{0}$, DES in lincomycin-treated samples was significantly higher than in the control and DTT treatments, and did not change during the day, even when EPAR at the ice-water interface decreased. At 17:00 h, $F_{\mathrm{v}} / F_{\mathrm{m}}$ in DTT-treated samples was at $80 \%$ of the initial ratio, as for the control, while $F_{\mathrm{v}} / F_{\mathrm{m}}$ in lincomycin-treated samples was only at $40 \%$ of the initial ratio. However, DES in lincomycin-treated samples was the highest by a factor of 2 in comparison with other treatments.

\section{Effect of high light exposure on the photophysiology of ice algae released from bottom sea ice}

The aim of the third experiment (Table 1) was to assess the photoprotective capability of bottom ice algae when exposed to a sudden increase in irradiance, similar to what they would experience when carried into adjacent ice-free areas by surface currents after their release in the water column. Our hypothesis was that bottom ice algae from thin snow cover should be less light-sensitive than those from thick snow cover. To test this hypothesis, bottom ice algae were collected under thin and thick snow covers and exposed to incident irradiance (itg. 8). During the experiment, incident $E_{\mathrm{PAR}}$ was constant at an average of $1107 \pm 95 \mu \mathrm{mol}$ photons $\mathrm{m}^{-2} \mathrm{~s}^{-1}$ (Fig. 8a).

$F_{\mathrm{v}} / F_{\mathrm{m}}$ of bottom ice algae from thin and thick snow covers reached the same minimum value (ca. 0.05 ), illustrating a high level of photoinhibition (i.e. $-75 \%$ in $F_{\mathrm{v}} / F_{\mathrm{m}}$ ) when exposed to these over-saturating light intensities (10 times higher than the maximum average of bottom ice; see Fig. 8a) after a $3 \mathrm{~h}$ period. Nevertheless, the pattern of $F_{\mathrm{v}} / F_{\mathrm{m}}$ variations was very different 
465

466

467

468

469

470

471

472

473

474

475

476

477

478

479

480

481

482

483

484

485

486

487

488

489

490

491

between the 2 algal communities (Fig. $8 b$ ). For algae from thin snow cover, $F_{\mathrm{v}} / F_{\mathrm{m}}$ decreased progressively during the first $2 \mathrm{~h}$ of light exposure, and sharply during the last hour of exposure. For thick snow cover, $F_{\mathrm{v}} / F_{\mathrm{m}}$ showed a rapid drop close to 0 after the first $0.5 \mathrm{~h}$, followed by a slight but significant recovery to its final value.

At the same time, ice algae underwent substantial changes in pigment content, with a Tchl $a$ decrease (Fig. 8c) and DES increase (Fig. 8d); mean values were significantly different under thin and thick snow cover conditions (paired $t$-test, $t=12.394, \mathrm{df}=5, \mathrm{p}<0.001$ for Tchl $a$ and Wilcoxon signed rank test, $W=21, \mathrm{p}<0.05$ for DES). More specifically, under thin snow cover, Tchl $a$ decreased by $20 \%$ (from 1228 to $987 \mu \mathrm{g}$ chl $a \mathrm{l}^{-1}$ ) during the first $0.5 \mathrm{~h}$ of light exposure, followed by a slower but consistent decrease of $23 \%$ (from 987 to $759 \mu \mathrm{g} \mathrm{chl} \mathrm{a}^{-1}$ ) during the rest of the experiment. Simultaneously, DES increased from a value of 0.09 to 0.19 wt:wt during the first $0.5 \mathrm{~h}$ of light exposure and then stabilized around a value of $0.18 \mathrm{wt}$ :wt at end of the experiment. Under thick snow cover, Tchl $a$ followed a consistent decrease of 33\%, from 146 to $98 \mu \mathrm{g} \mathrm{l}^{-1}$ during the $3 \mathrm{~h}$ light exposure, while DES did not show significant changes, varying between 0.12 and $0.15 \mathrm{wt}$ :wt.

\section{DISCUSSION}

\section{Effect of snow cover on the taxonomic composition and photosynthetic} properties of bottom ice algae

According to previous studies at similar latitudes (ca. 70 N) (Renaud et al. 2007, AlouFont et al. 2013), the ice algal bloom starts between the end of March and beginning of April. In 2015, snow events around mid-May may have extended the ice algal bloom period by reducing $E_{\text {PAR }}$ penetration through the ice and thermally insulating the ice, which consequently delayed the melting process that usually terminates the bloom (e.g. Fortier et al. 2002, Mundy et al. 2005, Campbell et al. 2015). Thus, a positive relationship was observed between snow depth and Tchl $a$ concentration $(\mathrm{r}=0.693, \mathrm{p}<0.001)$, contrary to observations for early spring when light is limiting (Mundy et al. 2007, Alou-Font et al. 2013), but consistent with later bloom conditions (Campbell et al. 2015, Leu et al. 2015). 
Under both snow covers (thin and thick), the bottom ice algal community was mainly composed of diatoms (Fig. 4), as confirmed by Imaging Flow CytoBot data (P. L. Grondin pers. comm.) and as also reported previously (Alou-Font et al. 2013). Whilst taxonomic studies in the Arctic have shown that pennate diatoms contribute to at least $68 \%$ of the abundance of total ice algae (von Quillfeldt et al. 2003, Poulin et al. 2011), we observed a change from a dominance of pennate diatoms (e.g. diatoms Type 2) before snow events to centric diatoms (e.g. diatoms Type 1) during the snowmelt period. This diatom community change from the beginning to the end of spring has recently been observed in Dease Strait (Nunavut) during spring 2014 (Campbell et al. 2017). The transition from pennate to centric diatoms could be associated with the increase in light conditions and changes in physico-chemical properties (e.g. lower brine salinity and limited nutrient availability) of sea ice through the spring season. Furthermore, before snow events (e.g. at the beginning of spring) the algal community under thick snow cover was more heterogeneous, with the presence of cryptophytes and dinoflagellates. This observation was already documented by Różańska et al. (2009) in Franklin Bay, where diatoms were less abundant in sea ice under thick snow than under thin snow. They suggested that flagellates were more abundant due to their capacity to be mixotrophic instead of purely autotrophic (Sherr et al. 2013, Unrein et al. 2014). Thus, the algal composition changed markedly depending on snow cover but also over the different sampling periods.

As the snow melting period progresses, ice algae grow and need to acclimate to higher light intensities. Before snow events, PPC:PSC and (DD+DT):Tchl $a$ ratios were higher under thin than thick snow cover conditions (Fig. 3b,c) in accordance with higher light transmittance (Brunelle et al. 2012, Alou-Font et al. 2013). These findings were further corroborated by a lower $\alpha$, a higher rETR max and a higher $E_{k}$ under thin snow cover (details in Table 2), a typical high-light acclimation response (McMinn \& Hegseth 2004, Manes \& Gradinger 2009, Katayama \& Taguchi 2013).

During the snowmelt period, bottom ice algae can be exposed for prolonged periods to relatively high light conditions. Thus, they need to be able to protect themselves through, e.g. the synthesis of carotenoids and other antioxidants. The lower bottom ice PPC:PSC ratio (up to 0.81) than previously reported in the Canadian Beaufort Sea (up to 1-3.5 wt:wt; Alou-Font et al. 2013) could be due to the dominance of centric diatoms at the end of spring instead of pennate diatoms. 
However, the (DD+DT):Tchl $a$ ratio (up to 0.28 ) was within the range of values reported in the Canadian Beaufort Sea (0.04 to 0.8 wt:wt; Alou-Font et al. 2013), in a high Arctic fjord of Svalbard (0.03 to 0.08 wt:wt; Leu et al. 2010) and in Antarctica (0.08 to 0.1 wt:wt; Petrou et al. 2011, Arrigo 2014). The significant positive relationships between the PPC:PSC and $(\mathrm{DD}+\mathrm{DT}):$ Tchl $a$ ratios and EPAR transmittance at the ice-water interface during the snowmelt period confirms the strong relationship between light transmittance and carotenoids synthesis. By rapid activation of the $\mathrm{XC}$ and a rapid decline in photochemical efficiency, bottom ice algae possess a high level of plasticity in their light-acclimation capabilities. Our observations and the previous work of Petrou et al. (2011) in Antarctica confirm that non-photochemical quenching (NPQ) via XC activation would be the preferred method of regulating energy flow to PSII and photoprotection. In addition, the dominance of centric diatoms at the end of spring (Campbell et al. 2017, our Fig. 4) seems to represent the ideal algal community to seed an under-ice bloom. In fact, centric diatoms, as observed with Chaetoceros sp. by Petrou \& Ralph (2011), possess a high plasticity and are able to acclimate well to all environments, but perform best under pelagic conditions. Thus, in a future Arctic where sea ice will be thinner and consequently light intensities higher, the bottom ice algae could shift from pennate to centric diatoms, based on their differential photoacclimative ability.

\section{Ice algal photophysiological response: the 'cellular light memory' hypothesis}

When comparing the photophysiological response of ice algae as a function of snow depth before and during snow events, we observed that ice algae under thick snow cover were more light-sensitive, as indicated by the more rapid decrease of $F_{\mathrm{v}} / F_{\mathrm{m}}$ under light exposure from 10 to $200 \mu \mathrm{mol}$ photons $\mathrm{m}^{-2} \mathrm{~s}^{-1}$ (Fig. 5). Before snow events, the algal community under thick snow cover was more heterogeneous with the presence of cryptophytes and dinoflagellates, which are more sensitive to greater light intensities than diatoms (Richardson et al. 1983, Demers et al. 1991). Differences in photoacclimative and photoprotective strategies have been reported between diatoms and other algal clades (Rajanahally et al. 2015, Petrou et al. 2016, Lacour et al. 2017) as well as among diatom strains (Lavaud \& Goss 2014, Barnett et al. 2015, Petrou et al. 2016). In addition, the lower DES before the experiment $\left(T_{0}\right)$ in this algal community confirmed that it was low-light acclimated before the experiment. Since our experiments were performed under constant temperature (ca. $-1.2^{\circ} \mathrm{C}$ ) and nutrient-sufficient conditions, the differences in 
$F_{\mathrm{v}} / F_{\mathrm{m}}$ and DES between thin and thick snow cover depths could be attributed to the algal community composition and/or the light history of the cells. However, during snow events, the algal community was similar between snow covers, thus the difference in light sensitivity, such as the quicker response of DES and the smaller decrease of $F_{\mathrm{v}} / F_{\mathrm{m}}$, must be associated with the different light history. The algal community and the light history are then 2 essential factors which must be taken into account when looking at photoprotection and photoacclimation of bottom ice algae.

The differential photophysiological response as a function of snow depth was even more pronounced when ice algae were exposed to over-saturating light stress (ca. $1000 \mu \mathrm{mol}$ photons $\mathrm{m}^{-2} \mathrm{~s}^{-1}$ for $3 \mathrm{~h}$ ) that mimicked their release from ice and exposure at the surface of open waters. Our experiment confirmed that bottom ice algae from thin snow cover were less light-sensitive than those from thick snow cover. Their light response was supported by their capacity to reduce excitation pressure on PSII $\left(F_{\mathrm{v}} / F_{\mathrm{m}}\right.$ relatively stable for $\left.2 \mathrm{~h}\right)$ due to a higher DES and synthesis of DT (1.75 times higher than in ice algae from thin snow cover). A similar response was observed in ice algae from Antarctic pack ice (Petrou et al. 2011). Higher DT synthesis illustrates well the response of diatoms to higher average irradiance (Wilhelm et al. 2014) as reported from different algal communities which inhabit substrates and which are dominated by diatoms, i.e. ice algal communities (Arrigo et al. 2010, Petrou et al. 2011, Katayama \& Taguchi 2013) as well as benthic diatoms that inhabit intertidal sediments (Laviale et al. 2015). Higher DT cellular content can originate from DD de-epoxidation and de novo synthesis when light conditions are harsher (Lavaud \& Goss 2014). Increased DT (and DD) synthesis was recently shown to be directly dependent on the redox state of the plastoquinone (PQ) pool (Lepetit et al. 2013) and thus on the excitation pressure on the photosynthetic machinery, and it is likely related to the parallel synthesis of specific PSII light-harvesting antenna proteins (LHCx; see Wu et al. 2012, Lepetit et al. 2017). Higher DT content provides a stronger capacity to prevent/limit the harmful effects of excess light exposure on photosynthetic efficiency, namely PSII photodamage (Wu et al. 2012, Lepetit et al. 2013) and lipid peroxidation of thylakoid membranes (Lepetit et al. 2010). DT acts via 2 main processes: the dissipation of excess excitation energy in PSII antenna through NPQ (Lavaud \& Goss 2014, Goss \& Lepetit 2015) and the direct scavenging of reactive oxygen species (ROS) as proposed by Lepetit et al. (2010). 
Surprisingly, ice algae under the same snow depth but during different time periods (ca. $25 \mathrm{~cm}$, i.e. thick snow before snow events and thin snow during snow events; Fig. 2a), did not show the same light response (Fig. 5b,c). For all light intensities, the $F_{\mathrm{v}} / F_{\mathrm{m}}$ decrease was stronger for ice algae under thick snow before snow events, indicating a higher light sensitivity. The ice algae under thin snow during snow events showed a similar response to those under thin snow before snow events (Fig. 5a,c) even if they had spent $13 \mathrm{~d}$ under the new light conditions (i.e. less light availability because of thicker snow cover) when the experiment took place. This observation suggests that ice algae from thin snow kept their acclimation status similar to that before the snow events, even if they were exposed to lower irradiance (due to snow events) for several days. A similar process, so-called 'cellular light memory', has been reported in higher plants and it can persist for several days (Szechyńska-Hebda et al. 2010, Karpiński \& Szechyńska-Hebda 2012). The cellular memory of excess light exposure is based on a complex network in plant tissues which starts in the plastids of leaves, and which orchestrates a physiological response to improve photoacclimation under changing light conditions. It is associated with photoelectrochemical retrograde signaling due in part to changes in PSII redox state, and with photoprotective processes such as the XC-related NPQ. Although diatoms are unicellular organisms, they possess a photoelectrophysiological activity across thylakoid membranes (Bailleul et al. 2015), a redox-based plastid-to-nucleus retrograde signaling pathway (Lepetit et al. 2013) and a strong NPQ tightly associated with the XC (Lavaud \& Goss 2014). Based on similar features for photochemistry and light dissipation between higher plants and diatoms, we surmise that diatoms also possess this process of cellular light memory.

\section{Photoprotective mechanisms in low-light acclimated algae}

Our study confirms that ice algae were adapted to very low light intensities, but could maintain photosynthesis over a range of irradiances corresponding to those measured at the icewater interface (up to ca. $100 \mu \mathrm{mol}$ photons $\mathrm{m}^{-2} \mathrm{~s}^{-1}$; Fig. 7a). Indeed, fast (within $30 \mathrm{~min}$ light exposure) and major changes in PSII photochemistry (decrease in $F_{\mathrm{v}} / F_{\mathrm{m}}$ ) and DD de-epoxidation (increased DES) were observed for irradiance of $100 \mu \mathrm{mol}$ photons $\mathrm{m}^{-2} \mathrm{~s}^{-1}$. Below this light intensity, the non-significant changes in $F_{\mathrm{v}} / F_{\mathrm{m}}$ and DES indicate that bottom ice algae were acclimated to an irradiance ranging between 50 and $100 \mu \mathrm{mol}$ photons $\mathrm{m}^{-2} \mathrm{~s}^{-1}$ and probably closer to $50 \mu \mathrm{mol}$ photons $\mathrm{m}^{-2} \mathrm{~s}^{-1}$ according to our experiments. This observation agrees with the 
results of Juhl \& Krembs (2010), who showed that Nitzschia frigida (the most abundant bottom ice pennate diatom in the Arctic) could acclimate up to $110 \mu \mathrm{mol}$ photons $\mathrm{m}^{-2} \mathrm{~s}^{-1}$ in laboratory conditions. Also similar to our data, Cota \& Horne (1989) reported that the optimal photosynthetic irradiance range for ice algae was from 16 to $100 \mu \mathrm{mol}$ photons $\mathrm{m}^{-2} \mathrm{~s}^{-1}$. When exposed to $200 \mu \mathrm{mol}$ photons $\mathrm{m}^{-2} \mathrm{~s}^{-1}$, and despite the significant increase of DES index, ice algae underwent an important drop down of their photochemistry as indicated by the very low $F_{\mathrm{v}} / F_{\mathrm{m}}$ (ca. 0.3) and its only partial recovery, which well illustrates PSII photoinactivation and/or photodamage (Petrou et al. 2010). This light-response has already been reported for ice algae in Antarctica (Petrou et al. 2010, 2011). In contrast, studies in Greenland and Antarctica found that highly shade-adapted ice diatoms showed a photoinhibitory response at irradiances as low as 25 to $50 \mu \mathrm{mol}$ photons $\mathrm{m}^{-2} \mathrm{~s}^{-1}$ (e.g. Rysgaard et al. 2001, McMinn et al. 2007, Mangoni et al. 2009, Ryan et al. 2011). Nutrient availability (Cota \& Horne 1989) could well explain this discrepancy with our data as well as differential photoadaptation abilities among diatom species and communities between our data and others (Laviale et al. 2015, Petrou et al. 2016). Thus, environmental (e.g. nutrient concentrations and light conditions depending on snow depth) and biological (e.g. algal community composition) conditions influence the photo-response of ice algae, which can acclimate to a range of irradiances from 25 up to $100 \mu \mathrm{mol}$ photons $\mathrm{m}^{-2} \mathrm{~s}^{-1}$ according to the literature and this study. It is noteworthy that ice algae could be more light resistant when aggregated (a behavioral feature we could not assess with the design of our experiments). In fact, aggregation of ice algae during spring and generated self-shading are 2 processes often mentioned in Arctic studies (Glud et al. 2002, Assmy et al. 2013, FernándezMéndez et al. 2014), and it could expand their range of light resistance beyond $100 \mu \mathrm{mol}$ photons $\mathrm{m}^{-2} \mathrm{~s}^{-1}$.

In order to better understand the photophysiological response of ice algae, we compared the effects of presence and absence of an inhibitor of de-epoxidation of DD into DT (i.e. DTT) and of PSII photodamage repair (i.e. lincomycin). This single experiment with duplicate samples gives us an idea of the relative importance of DT and PSII D1 protein synthesis in photoprotection and in the maintenance of photosynthesis under an irradiance range (ca. 50 to $100 \mu \mathrm{mol}$ photons $\mathrm{m}^{-2} \mathrm{~s}^{-1}$ ) that ice algae experience at the ice-water interface (Fig. 7a). Although this type of experiment has been previously conducted (DTT: Kudoh et al. 2003, 
Griffith et al. 2009; lincomycin: Petrou et al. 2010), this was the first time that such a combined protocol was applied on an Arctic ice algal community. As during our controlled experiments, bottom ice algae were able to maintain their photosynthetic capacity (mostly high and stable $\left.F_{\mathrm{v}} / F_{\mathrm{m}}\right)$ under these light conditions. Differential light-response between control conditions and inhibitor treatments indicate that PSII photochemical functionality was supported by both DT and D1-psbA protein synthesis with an apparently stronger photoprotective capacity by DT synthesized from DD de-epoxidation (i.e. $F_{\mathrm{v}} / F_{\mathrm{m}}$ decrease was significantly higher when DTT was added as compared to lincomycin). This is in agreement with previous reports on Antarctic bottom ice algae, showing that they are well adapted to their changing in situ light environment as indicated by no/low PSII photodamage due to DT and D1-psbA protein synthesis (Petrou et al. 2010, 2011). However, when ice algae were exposed to an over-saturating light stress (ca. 1000 $\mu$ mol photons $\mathrm{m}^{-2} \mathrm{~s}^{-1}$ ), their photochemical capacity was nearly abolished after $3 \mathrm{~h}$, although efficient DT-driven photoprotection occurred during the first $2 \mathrm{~h}$. This response could be associated with high EPAR but also with the presence of UVR in this experiment, while it was absent in the others. Some studies showed that pennate diatoms were relatively tolerant of UVR (Zacher et al. 2007, Wulff et al. 2008), while a recent study on ice algal communities in the Baltic Sea observed that UVR was one of the controlling factors (Enberg et al. 2015). In addition, studies on Antarctic algal cultures exposed to UVR observed an increase in mortality (McMinn et al. 1999), a reduction in photosynthesis (Schoeld et al. 1995, Villafañe et al. 2004) and a decline in productivity (Marcoval et al. 2007). Such light conditions can occur when ice algae released from sea ice are exported towards the surface of open waters along a receding ice edge. Our observation strongly points to the inability of ice algae to manage with a high rate of PSII photodamage generating photoinhibition. However, as mentioned above, they can also protect themselves via self-shading by forming aggregates when released into the water column (Glud et al. 2002, Assmy et al. 2013, Fernández-Méndez et al. 2014). This process enhances the sinking rate of sea ice algae, especially of diatoms (Raven \& Waite 2004, Aumack \& Juhl 2015), and their export to deeper water layers where they can feed both pelagic and benthic food webs (Kohlbach et al. 2016).

\section{CONCLUSIONS}


In this study, bottom ice algae were dominated by diatoms and were well adapted to daily and weekly changes in their light environment during Arctic spring. This is in agreement with previous studies in Antarctica (e.g. McMinn et al. 2007, Mangoni et al. 2009, Petrou et al. 2011, Rajanahally et al. 2015). Their rapid response to excess light exposure is supported by central photoprotective processes such as XC and the repair of photodamaged D1 protein in PSII. We found that the photoprotective ability of bottom ice algae depends on their light history, controlled by the overlying snow depth through its influence on light transmittance to the bottom ice environment. We propose that, in order to acclimate to their permanently changing light environment driven by snow events and winds, bottom ice algae perform 'cellular light memory' similar to higher plants (Szechyńska-Hebda et al. 2010). According to our data, cellular light memory can prolong over at least $2 \mathrm{wk}$, enabling ice algae to improve their photoacclimative response to changing light conditions over different periods (days vs. weeks).

In a context of global warming in the Arctic, it has been predicted that the snow cover will potentially undergo rapid changes during future Arctic spring due to the combined effects of an increase in snow events (Singarayer et al. 2006, AMAP 2011) yet a decrease in snow depth (Webster et al. 2014) and duration (Callaghan et al. 2011, Derksen \& Brown 2012, Overland et al. 2014). This will directly and strongly affect the light availability for bottom ice algae. The high plasticity of ice algae to acclimate to relatively large variations in irradiance over very different time scales suggests that ice algae may be more resilient to future changes than previously anticipated. However, ice algae will likely face more frequent light stress due to disturbed sea ice dynamics and especially an earlier melt (Leu et al. 2016). As shown in our study, bottom ice algae can only sustain reversible photoinhibition under high-light conditions for a limited period (less than $3 \mathrm{~h}$ ), greatly reducing their productivity and survival potential once released into the water column at the ice edge (Yamamoto et al. 2014). In this context, the timing between snowmelt, the release of ice algae and their stage of development will certainly affect their photoacclimative and photoprotective responses. Thus, it would be of interest to achieve similar light-response experiments on bottom ice algae during the decline of their spring bloom and the beginning of their release from sea ice.

Acknowledgements. We acknowledge the contributions of the Canada Excellence Research Chair (CERC) and Canada Research Chair (CRC) programs, the Natural Sciences and Engineering Research Council of Canada (NSERC), the Canada Foundation for Innovation (CFI), Canada 
Economic Development, and Fonds de recherche du Québec - Nature et technologies (FRQNT) through the Québec-Océan research cluster. The GreenEdge project is funded by the following French and Canadian programs and agencies: ANR (Contract \#111112), CNES (project \#131425), IPEV (project \#1164), CSA, Fondation Total, ArcticNet, LEFE, and the French Arctic Initiative (GreenEdge project). This project would not have been possible without the support of the Hamlet of Qikiqtarjuaq and the members of the community as well as the Inuksuit School and its Principal J. Arsenault. The project was conducted under the scientific coordination of the Canada Excellence Research Chair on Remote sensing of Canada's new Arctic frontier and the CNRS \& Université Laval Takuvik Joint International laboratory (UMI3376). The field campaign was successful thanks to the contribution of J. Ferland, G. Bécu, C. Marec, J. Lagunas, F. Bruyant, J. Larivière, E. Rehm, S. Lambert-Girard, C. Aubry, C. Lalande, A. LeBaron, C. Marty, J. Sansoulet, D. Christiansen-Stowe, A. Wells, M. Benoît-Gagné, E. Devred and M.-H. Forget from the Takuvik laboratory, as well as F. Pinczon du Sel and E. Brossier from Vagabond. We also thank the CCGS 'Amundsen' and the Polar Continental Shelf Program for their in-kind contribution in polar logistic and scientific equipment. The authors thank M. Blais, J. Charette and M. Simard for their invaluable help with the analysis and identification of pigments. We also thank the participants of the Green Edge ice camp for their precious help during the experiments and G. Neukermans for achieving C-OPS profiles. We are grateful to P. Raimbaud (UMR 6117 CNRS) for the nutrient analysis and H. Claustre, J. Ras and C. Dimier (SAPIGH-Villefranche Oceanographic Laboratory) for HPLC analysis. We thank G. Joyal (P. Lajeunesse laboratory from Laval University) who provided the bathymetric data for the map. The authors are grateful to 3 anonymous reviewers whose constructive comments greatly improved the quality of the manuscript. This is a contribution to the research programs of ArcticNet, Québec-Océan, Arctic Science Partnership (ASP) and the Canada Excellence Research Chair unit at the Centre for Earth Observation Science.

\section{LITERATURE CITED}

Alou-Font E, Mundy CJ, Roy S, Gosselin M, Agustí S (2013) Snow cover affects ice algal pigment composition in the coastal Arctic Ocean during spring. Mar Ecol Prog Ser 474:89-104 https://doi.org/10.3354/meps10107 
Alou-Font E, Roy S, Agustí S, Gosselin M (2016) Cell viability, pigments and photosynthetic performance of Arctic phytoplankton in contrasting ice-covered and open-water conditions during the spring-summer transition. Mar Ecol Prog Ser 543:89-106 https://doi.org/10.3354/meps11562

AMAP (2011) Snow, water, ice and permafrost in the Arctic (SWIPA): climate change and the cryosphere. Arctic monitoring and assessment programme (AMAP), Oslo

Aminot A, Kérouel R (2007) Dosage automatique des nutriments dans les eaux marines: méthodes en flux continu. Edition Quae, Versailles

Arrigo KR (2014) Sea ice ecosystems. Annu Rev Mar Sci 6:439-467 https://doi.org/10.1146/annurev$\underline{\text { marine-010213-135103 }}$

Arrigo KR, Sullivan CW (1992) The influence of salinity and temperature covariation on the photophysiological characteristics of Antarctic sea ice microalgae. J Phycol 28:746-756 https://doi.org/10.1111/j.0022-3646.1992.00746.x

Arrigo KR, Kremer JN, Sullivan CW (1993) A simulated Antarctic fast-ice ecosystem. J Geophys Res 98:6929-6946 https://doi.org/10.1029/93JC00141

Arrigo K, Mock T, Lizotte MP (2010) Primary producers and sea ice. In: Thomas DN, Dieckmann GS (eds) Sea ice. Wiley-Blackwell, West Sussex, p 283-325

Assmy P, Ehn JK, Fernández-Méndez M, Hop H and others (2013) Floating ice-algal aggregates below melting Arctic sea ice. PLOS ONE 8:e76599 https://doi.org/10.1371/journal.pone.0076599

Aumack CF, Juhl AR (2015) Light and nutrient effects on the settling characteristics of the sea ice diatom Nitzschia frigida. Limnol Oceanogr 60:765-776 https://doi.org/10.1002//no.10054Aumack CF, Juhl AR, Krembs C (2014) Diatom vertical migration within land-fast Arctic sea ice. J Mar Syst 139:496-504 https://doi.org/10.1016/j.jmarsys.2014.08.013

Bailleul B, Berne N, Murik O, Petrousos D and others (2015) Energetic coupling between plastids and mitochondria drives $\mathrm{CO}_{2}$ assimilation in diatoms. Nature 524:366-369 https://doi.org/10.1038/nature14599 
Ban A, Aikawa S, Hattori H, Sasaki H and others (2006) Comparative analysis of photosynthetic properties in ice algae and phytoplankton inhabiting Franklin Bay, the Canadian Arctic, with those in mesophilic diatoms during CASES 03-04. Polar Biosci 19:11-28

Barlow RG, Gosselin M, Legendre L, Therriault JC, Demers S, Llewellyn A, Mantoura RFC (1988) Photoadaptive strategies in sea-ice microalgae. Mar Ecol Prog Ser 45:145-152 https://doi.org/10.3354/meps045145

Barnett A, Méléder V, Blommaert L, Lepetit B and others (2015) Growth form defines physiological photoprotective capacity in intertidal benthic diatoms. ISME J 9:32-45 https://doi.org/10.1038/ismej.2014.105

Bates SS, Cota FC (1986) Fluorescence induction and photosynthetic responses of Arctic ice algae to sample treatment and salinity. J Phycol 70:421-429 https://doi.org/10.1111/j.15298817.1986.tb02484.xBelzile C, Johannessen SC, Gosselin M, Demers S, Miller WL (2000) Ultraviolet attenuation by dissolved and particulate constituents of first-year ice during late spring in an Arctic polynya. Limnol Oceanogr 45:1265-1273 https://doi.org/10.4319/10.2000.45.6.1265

Bidigare RR, Van Heukelem L, Trees CC (2005) Analysis of algal pigments by highperformance liquid chromatography. In: Andersen RA (ed) Algal culturing techniques. Elsevier Academic Press, Burlington, MA, p 327-346

Brunelle CB, Larouche P, Gosselin M (2012) Variability of phytoplankton light absorption in Canadian Arctic seas. J Geophys Res 117:C00G17 https://doi.org/10.1029/2011JC007345

$<$ edb $>$ Brunet C, Johnsen G, Lavaud J, Roy S (2011) Pigments and photoacclimation processes. In: Roy S, Llewellyn CA, Egeland ES, Johnsen G (eds) Phytoplankton pigments: characterization, chemotaxonomy and applications in oceanography. Cambridge University Press, Cambridge, p 445-454</edb $>$

$<$ jrn $>$ Callaghan TV, Johansson M, Brown RD, Groisman PY and others (2011) Multiple effects of changes in Arctic snow cover. Ambio 40:32-45 doi:10.1007/s13280-011-0213-x </jrn> $<$ jrn>Campbell K, Mundy CJ, Barber D, Gosselin M (2014) Remote estimates of ice algae biomass and their response to environmental conditions during spring melt. Arctic 67:375387 doi:10.14430/arctic4409</jrn> 
$<$ jrn $>$ Campbell K, Mundy CJ, Barber D, Gosselin M (2015) Characterizing the sea ice algae chlorophyll $a$ snow depth relationship over Arctic spring melt using transmitted irradiance. J Mar Syst 147:76-84 doi:10.1016/j.jmarsys.2014.01.008</jrn>

<unknown>Campbell K, Mundy CJ, Belzile C, Delaforge A, Rysgaard S (2017) Seasonal dynamics of algal and bacterial communities in Arctic sea ice under variable snow cover. Polar Biol, doi:10.1007/s00300-017-2168-2</unknown>

$<$ jrn $>$ Comiso JC, Hall DK (2014) Climate trends in the Arctic as observed from space. Wiley Interdiscip Rev Clim Change 5:389-409 PubMed doi:10.1002/wcc. 277</jrn>

$<$ jrn $>$ Cota GF (1985) Photoadaptation of high Arctic ice algae. Nature 315:219-222 $\underline{\text { doi: } 10.1038 / 315219 \mathrm{a} 0}</ \mathrm{jrn}>$ $<$ jrn $>$ Cota GF, Horne EPW (1989) Physical control of Arctic ice algal production. Mar Ecol Prog Ser 52:111-121 doi:10.3354/meps052111</jrn>

$<$ jrn>Demers S, Roy S, Gagnon R, Vignault C (1991) Rapid light-induced changes in cell fluorescence and in xanthophyll-cycle pigments of Alexandrium excavatum (Dinophyceae) and Thalassiosira pseudonana (Bacillariophyceae): a photo-protection mechanism. Mar Ecol Prog Ser 76:185-193 doi:10.3354/meps076185</jrn>

$<$ jrn>Derksen C, Brown R (2012) Spring snow cover extent reductions in the 2008-2012 period exceeding climate model projections. Geophys Res Lett 39:L19504 doi:10.1029/2012GL053387</jrn>

$<$ edb> Egeland ES, Garrido JL, Clementson L, Andresen K and others (2011) Data sheets aiding identification of phytoplankton carotenoids and chlorophylls. In: Roy S, Llewellyn CA, Egeland ES, Johnsen G (eds) Phytoplankton pigments: characterization, chemotaxonomy and applications in oceanography. Cambridge University Press, Cambridge, p 665-822</edb $>$ $<$ jrn>Ehn JK, Mundy CJ (2013) Assessment of light absorption within highly scattering bottom sea ice from under-ice light measurements: implications for Arctic ice algae primary production. Limnol Oceanogr 58:893-902 doi:10.4319/1o.2013.58.3.0893 $</$ jrn $>$ $<$ jrn>Eilers PHC, Peeters JCH (1988) A model for the relationship between light intensity and the rate of photosynthesis in phytoplankton. Ecol Modell 42:199-215 doi:10.1016/0304$\underline{3800(88) 90057-9}</ \mathrm{jrn}>$ 
$<$ jrn>Eker-Develi E, Berthon JF, Canuti E, Slabakova N, Moncheva S, Shtereva G, Dzhurova B (2012) Phytoplankton taxonomy based on CHEMTAX and microscopy in the northwestern Black Sea. J Mar Syst 94:18-32 doi:10.1016/j.jmarsys.2011.10.005</jrn>

<jrn>Enberg S, Piiparinen J, Majaneva M, Vähätalo AV, Autio R, Rintala JM (2015) Solar PAR and UVR modify the community composition and photosynthetic activity of sea ice algae. FEMS Microbiol Ecol 91:fiv102 PubMed doi:10.1093/femsec/fiv102</jrn>

<jrn>Fernández-Méndez M, Wenzhöfer F, Peeken I, Sørensen HL, Glud RN, Boetius A (2014) Composition, buoyancy regulation and fate of ice algal aggregates in the central Arctic Ocean. PLOS ONE 9:e107452 PubMed doi:10.1371/journal.pone.0107452</jrn>

$<$ jrn>Garrison DL, Buck KR (1986) Organism losses during ice melting: a serious bias in sea ice community studies. Polar Biol 6:237-239 doi:10.1007/BF00443401</jrn>

$<$ jrn $>$ Glud RN, Rysgaard S, Kühl M (2002) A laboratory study on $\mathrm{O}_{2}$ dynamics and photosynthesis in ice algal communities: quantification by microsensors, $\mathrm{O}_{2}$ exchange rates, ${ }^{14} \mathrm{C}$ incubations and a PAM fluorometer. Aquat Microb Ecol 27:301-311 doi:10.3354/ame027301</jrn>

$<$ jrn>Goss R, Jakob T (2010) Regulation and function of xanthophyll cycle-dependent photoprotection in algae. Photosynth Res 106:103-122 PubMed doi:10.1007/s11120-010$\underline{9536-\mathrm{x}}<$ jirn $>$

$<$ jrn $>$ Goss R, Lepetit B (2015) Biodiversity of NPQ. J Plant Physiol 172:13-32 PubMed doi:10.1016/j.jplph.2014.03.004</jrn>

$<$ jrn>Gosselin M, Legendre L, Demers S, Ingram RG (1985) Responses of sea-ice microalgae to climatic and fortnightly tidal energy inputs (Manitounuk Sound, Hudson Bay). Can J Fish Aquat Sci 42:999-1006 doi:10.1139/f85-125</jrn>

$<$ jrn $>$ Gosselin M, Levasseur M, Wheeler P, Horner RA, Booth B (1997) New measurements of phytoplankton and ice algal production in the Arctic Ocean. Deep Sea Res II 44:1623-1644 doi:10.1016/S0967-0645(97)00054-4</jrn>

$<$ jrn $>$ Griffith GP, Vennell R, Lamare MD (2009) Diadinoxanthin cycle of the bottom ice algal community during spring in McMurdo Sound, Antarctica. Polar Biol 32:623-636 doi:10.1007/s00300-008-0562-5</jrn $>$ 
$<$ jrn>Ha SY, Lee DB, Kang SH, Shin KH (2016) Strategy of photo-protection in phytoplankton assemblages in the Kongsfjorden, Svalbard, Arctic. Chin J Oceanology Limnol 34:1-12 doi:10.1007/s00343-015-4295-3</jrn>

$<$ jrn>Halverson MJ, Pawlowicz R (2013) High-resolution observations of chlorophyll-a biomass from an instrumented ferry: influence of the Fraser River plume from 2003 to 2006. Cont Shelf Res 59:52-64 doi:10.1016/j.csr.2013.04.010</jrn>

$<$ jrn> Johnsen G, Hegseth EN (1991) Photoadaptation of sea-ice microalgae in the Barents Sea. Polar Biol 11:179-184 doi:10.1007/BF00240206 </jrn>

$<$ jrn $>$ Juhl AR, Krembs C (2010) Effects of snow removal and algal photoacclimation on growth and export of ice algae. Polar Biol 33:1057-1065 doi:10.1007/s00300-010-0784-1</jrn>

$<$ jrn> Juhl AR, Krembs C, Meiners KM (2011) Seasonal development and differential retention of ice algae and other organic fractions in first-year Arctic sea ice. Mar Ecol Prog Ser 436:116 doi: $10.3354 / \mathrm{meps} 09277</ \mathrm{jrn}>$

$<$ jrn>Karpiński S, Szechyńska-Hebda M (2012) Cellular light memory, photo-electrochemical and redox retrograde signaling in plants. BioTechnologia 93:27-39 doi:10.5114/bta.2012.46566 $</ j \mathrm{jn}>$

$<$ jrn>Kashino Y, Kudoh S, Hayashi Y, Suzuki Y and others (2002) Strategies of phytoplankton to perform effective photosynthesis in the North Water. Deep Sea Res II 49:5049-5061 doi:10.1016/S0967-0645(02)00177-7 $<$ jrn $>$

$<$ jrn>Katayama T, Taguchi S (2013) Photoprotective responses of an ice algal community in Saroma-Ko Lagoon, Hokkaido, Japan. Polar Biol 36:1431-1439 doi:10.1007/s00300-013$\underline{1361-1</ \mathrm{jrn}>}$

$<$ jrn>Katayama T, Makabe R, Sampei M, Hattori H, Sasaki H, Taguchi S (2017) Photoprotection and recovery of photosystem II in the Southern Ocean phytoplankton. Polar Sci 12:5-11 doi:10.1016/j.polar.2016.12.003 $</ j r n>$

$<$ edb $>$ Kirk JTO (2011) Scalar irradiance. In: Light and photosynthesis in aquatic ecosystems, $3^{\text {rd }}$ edn. Cambridge University Press, Cambridge, p 143</edb $>$ 
$<$ jrn>Kirkwood DS (1992) Stability of solutions of nutrient salts during storage. Mar Chem 38:151-164 doi:10.1016/0304-4203(92)90032-6 $</ j r n>$

$<$ jrn>Kohlbach D, Graeve M, Lange BA, David C, Peeken I, Flores H (2016) The importance of ice algae-produced carbon in the central Arctic Ocean ecosystem: food web relationships revealed by lipid and stable isotope analyses. Limnol Oceanogr 61:2027-2044 doi:10.1002/lno. $10351</$ jrn $>$

$<$ jrn>Kropuenske LR, Mills MM, van Dijken GL, Bialey S, Robinson DH, Welschmeyer NA, Arrigo KR (2009) Photophysiology in two major Southern Ocean phytoplankton taxa: photoprotection in Phaeocystis antarctica and Fragilariopsis cylindrus. Limnol Oceanogr 54:1176-1196 doi:10.4319/1o.2009.54.4.1176 $</ j r n>$ <jrn>Kuczynska P, Jemiola-Rzeminska M, Strzalka K (2015) Photosynthetic pigments in diatoms. Mar Drugs 13:5847-5881 PubMed doi:10.3390/md13095847</jrn>

$<$ jrn>Kudoh S, Robineau B, Suzuki Y, Fujiyoshi Y, Takahashi M (1997) Photosynthetic acclimation and the estimation of temperate ice algal primary production in Saroma-ko Lagoon, Japan. J Mar Syst 11:93-109 doi:10.1016/S0924-7963(96)00031-0</jrn>

$<$ jrn>Kudoh S, Imura S, Kashino Y (2003) Xanthophyll-cycle of ice algae on the sea ice bottom in Saroma Ko lagoon, Hokkaido, Japan. Polar Biosci 16:86-97</jrn>

$<$ jrn>Kühl M, Glud RN, Borum J, Roberts R, Rysgaard S (2001) Photosynthetic performance of surface-associated algae below sea ice as measured with pulse amplitude modulated (PAM) fluorometer and $\mathrm{O}_{2}$ microsensors. Mar Ecol Prog Ser 223:1-14 doi:10.3354/meps223001 $<$ jrn $>$

$<$ jrn $>$ Lacour T, Larivière J, Babin M (2017) Growth, chl $a$ content, photosynthesis, and elemental composition in polar and temperate microalgae. Limnol Oceanogr 62:43-58 doi:10.1002/lno.10369 $<$ jrn $>$

$<$ jrn>Latasa M (2007) Improving estimations of phytoplankton class abundances using CHEMTAX. Mar Ecol Prog Ser 329:13-21 doi:10.3354/meps329013</jrn>

$<\mathrm{edb}>$ Lavaud J, Goss R (2014) The peculiar features of non-photochemical fluorescence quenching in diatoms and brown algae. In: Demming-Adams B, Garab G, Adams W III, 
Govindjee (eds) Non-photochemical quenching and energy dissipation in plants, algae and cyanobacteria. Springer, Dordrecht, p 421-443, doi:10.1007/978-94-017-9032-1</edb>

$<$ jrn $>$ Lavaud J, Rousseau B, van Gorkom H, Etienne AL (2002) Influence of the diadinoxanthin pool size on photoprotection in the marine planktonic diatom Phaeodactylum tricornutum. Plant Physiol 129:1398-1406 PubMed doi:10.1104/pp.002014</jrn>

$<$ jrn>Laviale M, Barnett A, Ezequiel J, Lepetit B and others (2015) Response of intertidal benthic microalgal biofilms to a coupled light-temperature stress: evidence for latitudinal adaptation along the Atlantic coast of southern Europe. Environ Microbiol 17:3662-3677 $\underline{\text { PubMed doi:10.1111/1462-2920.12728 }}<$ /jrn $>$

$<$ jrn> Lavoie D, Denman KL, Michel C (2005) Modeling ice algal growth and decline in a seasonally ice-covered region of the Arctic (Resolute Passage, Canadian Archipelago). J Geophys Res 110:C11009 doi:10.1029/2005JC002922</jrn>

$<$ jrn> Lazzara L, Nardello I, Gallo C, Mangoni O, Saggiomo V (2007) Light environment and seasonal dynamics of microalgae in the annual sea ice at Terra Nova Bay (Ross Sea, Antarctica). Antarct Sci 19:83-92 doi:10.1017/S0954102007000119</jrn> $<$ jrn>Legendre L, Ackley S, Dieckmann G, Gulliksen B and others (1992) Ecology of sea ice biota. Polar Biol 12:429-444</jrn $>$

$<$ jrn>Lepetit B, Volke D, Gilbert M, Wilhelm C, Goss R (2010) Evidence for the existence of one antenna-associated, lipid-dissolved and two protein-bound pools of diadinoxanthin cycle pigments in diatoms. Plant Physiol 154:1905-1920 PubMed doi:10.1104/pp.110.166454</jrn>

$<$ jrn $>$ Lepetit B, Sturm S, Rogato A, Gruber A and others (2013) High light acclimation in the secondary plastids containing diatom Phaeodactylum tricornutum is triggered by the redox state of the plastoquinone pool. Plant Physiol 161:853-865 PubMed doi:10.1104/pp.112.207811 $</$ jrn $>$ $<$ jrn> Lepetit B, Gélin G, Lepetit M, Sturm S and others (2017) The diatom Phaeodactylum tricornutum adjusts nonphotochemical fluorescence quenching capacity in response to dynamic light via fine-tuned Lhcx and xanthophyll cycle pigment synthesis. New Phytol 214:205-218 PubMed doi:10.1111/nph.14337</jrn> 
$<$ jrn>Leu E, Wiktor J, Søreide JE, Berge J, Falk-Petersen S (2010) Increased irradiance reduces food quality of sea ice algae. Mar Ecol Prog Ser 411:49-60 doi:10.3354/meps08647</jrn> $<$ jrn>Leu E, Mundy CJ, Assmy P, Campbell K and others (2015) Arctic spring awakening steering principles behind the phenology of vernal ice algae blooms. Prog Oceanogr 139:151-170 doi:10.1016/j.pocean.2015.07.012</jrn>

$<$ jrn> Leu E, Graeve M, Wulff A (2016) A (too) bright future? Arctic diatoms under radiation stress. Polar Biol 39:1711-1724 doi:10.1007/s00300-016-2003-1</jrn>

$<$ jrn>Lin H, Kuzminov FI, Park J, Lee SH, Falkowski PG, Gorbunov MY (2016) The fate of photons absorbed by phytoplankton in the global ocean. Science 351:264-267 PubMed doi:10.1126/science.aab2213 $<$ jrn>

$<$ jrn> Liu X, Huang B, Liu Z, Wang L, Wei H, Li C, Huang Q (2012) High-resolution phytoplankton diel variations in the summer stratified central Yellow Sea. J Oceanogr 68:913-927 doi:10.1007/s10872-012-0144-6</jrn>

$<$ jrn>Lizotte MP, Sullivan CW (1992) Photosynthetic capacity in microalgae associated with Antarctic pack ice. Polar Biol 12:497-502 doi:10.1007/BF00238188</jrn>

$<$ jrn>Loose B, Miller LA, Elliott S, Papakyriakou T (2011) Sea ice biogeochemistry and material transport across the frozen interface. Oceanography (Wash DC) 24:202-218 doi:10.5670/oceanog.2011.72</jrn>

$<$ jrn>Lund-Hansen LC, Hawes I, Sorrell BK, Nielsen MH (2014) Removal of snow cover inhibits spring growth of Arctic ice algae through physiological and behavioral effects. Polar Biol 37:471-481 doi:10.1007/s00300-013-1444-z $<$ jrn $>$

$<$ jrn>Mackey MD, Mackey DJ, Higgins HW, Wright SW (1996) CHEMTAX — a program for estimating class abundances from chemical markers: application to HPLC measurements of phytoplankton. Mar Ecol Prog Ser 144:265-283 doi:10.3354/meps144265</jrn>

$<$ jrn>Malviya S, Scalco E, Audic S, Vincent F and others (2016) Insights into global diatom distribution and diversity in the world's ocean. Proc Natl Acad Sci USA 113:E1516-E1525 PubMed doi:10.1073/pnas.1509523113 $</$ jrn $>$ 
956

957

958

959

960

961

962

963

964

965

966

967

968

969

970

971

972

973

974

975

976

977

978

979

980

981

982

983

984

$<$ jrn>Manes SS, Gradinger R (2009) Small scale vertical gradients of Arctic ice algal photophysiological properties. Photosynth Res 102:53-66 PubMed doi:10.1007/s11120-009$\underline{9489-0}</ \mathrm{jrn}>$

$<$ jrn>Mangoni O, Carrada GC, Modigh M, Catalano G, Saggiomo V (2009) Photoacclimation in Antarctic bottom ice algae: an experimental approach. Polar Biol 32:325-335 doi:10.1007/s00300-008-0517-x $<$ jrn $>$

$<$ jrn>Markus T, Stroeve JC, Miller J (2009) Recent changes in Arctic sea ice melt onset, freeze up, and melt season length. J Geophys Res Oceans 114:C12024 doi:10.1029/2009JC005436</jrn>

$<$ jrn>Maxwell K, Johnson GN (2000) Chlorophyll fluorescence — a practical guide. J Exp Bot 51:659-668 PubMed doi:10.1093/jexbot/51.345.659 </jrn>

$<$ jrn>McMinn A, Hegseth EN (2004) Quantum yield and photosynthetic parameters of marine microalgae from the southern Arctic Ocean, Svalbard. J Mar Biol Assoc UK 84:865-871 doi: $10.1017 / \mathrm{S} 0025315404010112 \mathrm{~h}</ \mathrm{jrn}>$

$<$ jrn>McMinn A, Hirawake T, Hamaoka T, Hattori H, Fukuchi M (2005) Contribution of benthic microalgae to ice covered coastal ecosystems in northern Hokkaido, Japan. J Mar Biol Assoc UK 85:283-289 doi:10.1017/S0025315405011173h</jrn>

$<$ jrn>McMinn A, Ryan KG, Ralph PJ, Pankowski A (2007) Spring sea-ice photosynthesis, primary productivity and biomass distribution in eastern Antarctica, 2002-2004. Mar Biol 151:985-995 doi:10.1007/s00227-006-0533-8</jrn>

$<$ jrn>McMinn A, Martin A, Ryan K (2010) Phytoplankton and sea ice algal biomass and physiology during the transition between winter and spring (McMurdo Sound, Antarctica). Polar Biol 33:1547-1556 doi:10.1007/s00300-010-0844-6</jrn>

$<$ jrn>Michel C, Legendre L, Demers S, Therriault JC (1988) Photo-adaptation of sea-ice microalgae in springtime: photosynthesis and carboxylating enzymes. Mar Ecol Prog Ser 50:177-185 doi:10.3354/meps050177</jrn>

$<$ jrn>Michel C, Ingram RG, Harris LR (2006) Variability in oceanographic and ecological processes in the Canadian Arctic Archipelago. Prog Oceanogr 71:379-401 doi:10.1016/j.pocean.2006.09.006 $</$ jrn $>$ 
985

986

987

988

989

990

991

992

993

994

995

996

997

998

999

1000

1001

1002

1003

1004

1005

1006

1007

1008

1009

1010

1011

$<$ bok>Mobley CD (1994) Light and water radiative transfer in natural waters. Academic Press, San Diego, $\mathrm{CA}</$ bok $>$

$<$ jrn>Mundy CJ, Barber DG, Michel C (2005) Variability of snow and ice thermal, physical and optical properties pertinent to sea ice algae biomass during spring. J Mar Syst 58:107-120 doi:10.1016/j.jmarsys.2005.07.003 $<$ jrn $>$

$<$ jrn>Mundy CJ, Ehn JK, Barber DG, Michel C (2007) Influence of snow cover and algae on the spectral dependence of transmitted irradiance through Arctic landfast first-year sea ice. J Geophys Res 112:C03007 doi:10.1029/2006JC003683</jrn>

$<\mathrm{jrn}>$ Nicolaus M, Katlein C, Maslanik J, Hendricks S (2012) Changes in Arctic sea ice result in increasing light transmittance and absorption. Geophys Res Lett 39:L24501 doi:10.1029/2012GL053738 $<$ jrn $>$

$<$ jrn>Olaizola M, La Roche J, Kolber Z, Falkowski PG (1994) Non-photochemical quenching and the diadinoxanthin cycle in a marine diatom. Photosynth Res 41:357-370 PubMed doi:10.1007/BF00019413</jrn>

$<$ jrn>Overland JE, Wang M, Walsh JE, Stroeve JC (2014) Future Arctic climate changes: adaptation and mitigation time scales. Earths Futur 2:68-74 doi:10.1002/2013EF000162 $<$ jrn $>$

$<$ jrn>Papaioannou G, Papanikolaou N, Retalis D (1993) Relationships of photosynthetically active radiation and shortwave irradiance. Theor Appl Climatol 48:23-27 doi:10.1007/BF00864910</jrn>

<jrn>Parésys G, Rigart C, Rousseau B, Wong AWM, Fan F, Barbier JP, Lavaud J (2005) Quantitative and qualitative evaluation of phytoplankton communities by trichromatic chlorophyll fluorescence excitation with special focus on cyanobacteria. Water Res 39:911921 PubMed doi:10.1016/j.watres.2004.12.005 $<$ jrn> $<$ jrn $>$ Parkhill JP, Maillet G, Cullen JJ (2001) Fluorescence-based maximal quantum yield for PSII as a diagnostic of nutrient stress. J Phycol 37:517-529 doi:10.1046/j.1529$\underline{8817.2001 .037004517 . \mathrm{x}}</ \mathrm{jrn}>$ 
1012 <jrn>Pavlov AK, Taskjelle T, Kauko HM, Hamre B and others (2017) Altered inherent optical 1013 properties and estimates of the underwater light field during an Arctic under-ice bloom of 1014 Phaeocystis pouchetii. J Geophys Res 122:4939-4961 doi:10.1002/2016JC012471</jrn>

$1015<$ jrn>Perovich DK (2005) On the aggregate-scale partitioning of solar radiation in Arctic sea ice 1016 during the Surface Heat Budget of the Arctic Ocean (SHEBA) field experiment. J Geophys 1017 Res 110:C03002 doi:10.1029/2004JC002512</jrn>

$1018<$ jrn>Petrou K, Ralph PJ (2011) Photosynthesis and net primary productivity in three Antarctic 1019 diatoms: possible significance for their distribution in the Antarctic marine ecosystem. Mar 1020 Ecol Prog Ser 437:27-40 doi:10.3354/meps09291</jrn>

$1021<$ jrn>Petrou K, Hill R, Brown CM, Campbell DA, Doblin MA, Ralph PJ (2010) Rapid 1022 photoprotection in sea-ice diatoms from the East Antarctic pack ice. Limnol Oceanogr $1023 \quad 55: 1400-1407$ doi:10.4319/lo.2010.55.3.1400 $</ j r n>$

1024 < jrn>Petrou K, Hill R, Doblin MA, McMinn A, Johnson R, Wright SW, Ralph PJ (2011) 1025 Photoprotection of sea-ice microalgal communities from the East Antarctic pack ice. J 1026 Phycol 47:77-86 PubMed doi:10.1111/j.1529-8817.2010.00944. $x<$ jrn $>$

$1027<$ jrn>Petrou K, Kranz SA, Trimborn S, Hassler CS and others (2016) Southern Ocean 1028 phytoplankton physiology in a changing climate. J Plant Physiol 203:135-150 PubMed $1029 \quad$ doi:10.1016/j.jplph.2016.05.004</jrn>

1030 < jrn>Poulin M, Daugbjerg N, Gradinger R, Ilyash L, Ratkova T, von Quillfeldt C (2011) The 1031 pan-Arctic biodiversity of marine pelagic and sea-ice unicellular eukaryotes: a first-attempt 1032 assessment. Mar Biodivers 41:13-28 doi:10.1007/s12526-010-0058-8</jrn>

$1033<$ jrn>Rajanahally MA, Lester PJ, Convey P (2015) Aspects of resilience of polar sea ice algae to 1034 changes in their environment. Hydrobiologia 761:261-275 doi:10.1007/s10750-015-2362$1035 \quad \underline{6}</ j \mathrm{jn}>$

$1036<\mathrm{jrn}>$ Ras J, Claustre H, Uitz J (2008) Spatial variability of phytoplankton pigment distributions 1037 in the subtropical South Pacific Ocean: comparison between in situ and predicted data.

1038 Biogeosciences 5:353-369 doi:10.5194/bg-5-353-2008 </jrn $>$

$1039<\mathrm{jrn}>$ Raven JA, Waite AM (2004) The evolution of silicification in diatoms: Inescapable sinking 1040 and sinking as escape? New Phytol 162:45-61 doi:10.1111/j.1469-8137.2004.01022. $<$ <jrn> 
1041 < jrn>Renaud PE, Riedel A, Michel C, Morata N, Gosselin M, Juul-Pedersen T, Chiuchiolo A

1042 (2007) Seasonal variation in benthic community oxygen demand: A response to an ice algal

1043 bloom in the Beaufort Sea, Canadian Arctic? J Mar Syst 67:1-12

1044 doi:10.1016/j.jmarsys.2006.07.006 $<$ jrn $>$

$1045<\mathrm{jrn}>$ Richardson K, Beardall J, Raven JA (1983) Adaptation of unicellular algae to irradiance:

1046 an analysis of strategies. New Phytol 93:157-191 doi:10.1111/j.1469-

$1047 \quad \underline{8137.1983 . t b 03422 . x}</ \mathrm{jrn}>$

$1048<$ jrn>Riedel A, Michel C, Gosselin M, LeBlanc B (2008) Winter-spring dynamics in sea-ice

1049 carbon cycling in the coastal Arctic Ocean. J Mar Syst 74:918-932

$1050 \quad$ doi:10.1016/j.jmarsys.2008.01.003 $<$ /jrn>

1051 <jrn>Różańska M, Gosselin M, Poulin M, Wiktor JM, Michel C (2009) Influence of

1052 environmental factors on the development of bottom ice protist communities during the

1053 winter-spring transition. Mar Ecol Prog Ser 386:43-59 doi:10.3354/meps08092</jrn>

$1054<$ jrn>Ryan KG, Ralph P, McMinn A (2004) Acclimation of Antarctic bottom-ice algal

1055 communities to lowered salinities during melting. Polar Biol 27:679-686

1056 doi:10.1007/s00300-004-0636-y</jrn>

$1057<$ jrn>Ryan KG, Cowie ROM, Liggins E, McNaughtan D, Martin A, Davy SK (2009) The short1058 term effect of irradiance on the photosynthetic properties of Antarctic fast-ice microalgal 1059 communities. J Phycol 45:1290-1298 PubMed doi:10.1111/j.1529-8817.2009.00764.x < jrn>

$1060<$ jrn>Ryan KG, Tay ML, Martin A, McMinn A, Davy SK (2011) Chlorophyll fluorescence 1061 imaging analysis of the responses of Antarctic bottom-ice algae to light and salinity during 1062 melting. J Exp Mar Biol Ecol 399:156-161 doi:10.1016/j.jembe.2011.01.006</jrn>

1063 <jrn>Rysgaard S, Kühl M, Glud RN, Hansen JW (2001) Biomass, production and horizontal 1064 patchiness of sea ice algae in a high-Arctic fjord (Young Sound, NE Greenland). Mar Ecol 1065 Prog Ser 223:15-26 doi:10.3354/meps223015 $<$ jrn $>$

1066 <rn>Sakshaug E, Slagstad D (1991) Light and productivity of phytoplankton in polar marine 1067 ecosystems: a physiological view. Polar Res 10:69-85 doi:10.3402/polar.v10i1.6729</jrn>

$1068<$ jrn>Screen JA, Simmonds I (2012) Declining summer snowfall in the Arctic: causes, impacts 1069 and feedbacks. Clim Dyn 38:2243-2256 doi:10.1007/s00382-011-1105-2</jrn> 
$1070<\mathrm{jrn}>$ Screen JA, Simmonds I, Keay K (2011) Dramatic interannual changes of perennial Arctic 1071 sea ice linked to abnormal summer storm activity. J Geophys Res 116:D15105

1072 doi:10.1029/2011JD015847</jrn>

$1073<$ jrn>Sherr EB, Sherr BF, Ross C (2013) Microzooplankton grazing impact in the Bering Sea

1074 during spring sea ice conditions. Deep Sea Res II 94:57-67

$1075 \quad$ doi:10.1016/j.dsr2.2013.03.019 $</ j r n>$

$1076<$ jrn> Singarayer JS, Bamber JL, Valdes PJ (2006) Twenty-first-century climate impacts from a

1077 declining Arctic sea ice cover. J Clim 19:1109-1125 doi:10.1175/JCLI3649.1</jrn>

$1078<$ jrn $>$ Smith REH, Harrison WG, Harris LR, Herman AW (1990) Vertical fine structure of

1079 particulate matter and nutrients in sea ice of the high Arctic. Can J Fish Aquat Sci 47:1348-

$1080 \quad 1355$ doi:10.1139/f90-154 $</$ jrn $>$

$1081<$ jrn>Stroeve JC, Serreze MC, Holland MM, Kay JE, Malanik J, Barrett AP (2012) The Arctic's

1082 rapidly shrinking sea ice cover: a research synthesis. Clim Change 110:1005-1027

1083 doi:10.1007/s10584-011-0101-1 </jrn>

1084 < jrn>Szechyńska-Hebda M, Kruk J, Górecka M, Karpińska B, Karpiński S (2010) Evidence for

1085 light wavelength-specific photoelectrophysiological signaling and memory of excess light

1086 episodes in Arabidopsis. Plant Cell 22:2201-2218 $\underline{\text { PubMed }}$

$1087 \quad$ doi: $10.1105 /$ tpc. $109.069302</$ jrn $>$

1088 < jrn> Unrein F, Gasol JM, Not F, Fom I, Massana R (2014) Mixotrophic haptophytes are key

1089 bacterial grazers in oligotrophic coastal waters. ISME J 8:164-176 PubMed

$1090 \quad$ doi:10.1038/ismej.2013.132</jrn $>$

$1091<$ jrn $>$ Van Heukelem L, Thomas CS (2001) Computer-assisted high-performance liquid

1092 chromatography method development with applications to the isolation and analysis of

1093 phytoplankton pigments. J Chromatogr A 910:31-49 PubMed doi:10.1016/S0378-

$1094 \quad \underline{4347(00) 00603-4}<$ <jrn $>$

$1095<$ jrn > von Quillfeldt CH, Ambrose WG, Clough LM (2003) High number of diatom species in

1096 first-year ice from the Chukchi Sea. Polar Biol 26:806-818 doi:10.1007/s00300-003-0549-

$1097 \quad \underline{1}</ \mathrm{jrn}>$ 
$1098<$ jrn $>$ Wang L, Huang B, Liu X, Xiao W (2015) The modification and optimizing of the

1099 CHEMTAX running in the South China Sea. Acta Oceanol Sin 34:124-131

$1100 \quad$ doi:10.1007/s13131-015-0621-z $</ j r n>$

$1101<$ jrn $>$ Wassmann P, Duarte CM, Agusti S, Sejr MK (2011) Footprints of climate change in the

1102 Arctic marine ecosystem. Glob Change Biol 17:1235-1249 doi:10.1111/j.1365-

$1103 \quad \underline{2486.2010 .02311 . x}</$ jrn $>$

1104 <jrn>Webster MA, Rigor IG, Nghiem SV, Kurtz NT, Farrell SL, Perovich DK, Sturm M (2014)

1105 Interdecadal changes in snow depth on Arctic sea ice. J Geophys Res 119:5395-5406

$1106 \quad$ doi:10.1002/2014JC009985 $</$ jrn $>$

1107 <jrn> Wilhelm C, Jungandreas A, Jakob T, Goss R (2014) Light acclimation in diatoms: from

1108 phenomenology to mechanisms. Mar Genomics 16:5-15 PubMed

$1109 \quad$ doi:10.1016/j.margen.2013.12.003 $</$ jrn $>$

$1110<$ jrn $>$ Wright SW, Ishikawa A, Marchant HJ, Davidson AT, van den Enden RL, Nash G (2009)

1111 Composition and significance of picophytoplankton in Antarctic waters. Polar Biol 32:797-

1112808 doi:10.1007/s00300-009-0582-9 $</$ jrn $>$

$1113<$ jrn>Wu H, Roy S, Alami M, Green BR, Campbell DA (2012) Photosystem II

1114 photoinactivation, repair, and protection in marine centric diatoms. Plant Physiol 160:464-

$1115 \quad 476$ PubMed doi:10.1104/pp.112.203067</jrn $>$

$1116<$ jrn>Yamamoto S, Michel C, Gosselin M, Demers S, Fukuchi M, Taguchi S (2014)

1117 Photosynthetic characteristics of sinking microalgae under the sea ice. Polar Sci 8:385-396

1118 doi:10.1016/j.polar.2014.07.007 $<$ jrn $>$

$1119<$ jrn>Zapata M, Rodriguez F, Garrido JL (2000) Separation of chlorophylls and carotenoids from

1120 marine phytoplankton: a new HPLC method using a reversed phase $\mathrm{C}_{8}$ column and pyridine-

1121 containing mobile phases. Mar Ecol Prog Ser 195:29-45 doi:10.3354/meps195029</jrn>

1122 < jrn>Zonneveld C (1998) Photoinhibition as affected by photoacclimation in phytoplankton: a

1123 model approach. J Theor Biol 193:115-123 doi:10.1006/jtbi.1998.0688</jrn> 
1124 Table 1. Details of the 3 different experiments conducted during this study. DES: de-epoxidation state; PSII: photosystem II; DTT:

1125 dithiothreitol

\begin{tabular}{|c|c|c|c|c|c|c|c|}
\hline Expt & Snow cover & Objective & Period & Light source & $\begin{array}{l}\text { Light } \\
\text { exposure }\end{array}$ & $\begin{array}{l}\text { Recovery } \\
\text { period }\end{array}$ & $\begin{array}{l}\text { Inhibitor } \\
\text { treatment }\end{array}$ \\
\hline 1 & Thin and thick & $\begin{array}{l}\text { To assess the short-term effect of irradiance } \\
\text { range observed at the ice-water interface on the } \\
\text { photophysiological response of bottom ice algae }\end{array}$ & $\begin{array}{l}\text { Before and } \\
\text { during snow } \\
\text { events }\end{array}$ & $\begin{array}{l}\text { Cool white LEDs: } 10,50, \\
100,200 \mu \mathrm{mol} \mathrm{m}^{-2} \mathrm{~s}^{-1}\end{array}$ & $3 \mathrm{~h}$ & $\begin{array}{l}\text { Yes: } 2 \mathrm{~h} \\
<5 \mu \mathrm{mol} \mathrm{m} \mathrm{m}^{-2} \mathrm{~s}^{-1}\end{array}$ & No \\
\hline 2 & Thin & $\begin{array}{l}\text { To determine the respective importance of DES } \\
\text { and of the synthesis of PSII D1 protein to support } \\
\text { bottom ice algae in maintaining their } \\
\text { photochemical performance when exposed to } \\
\text { their natural light environment }\end{array}$ & $\begin{array}{l}\text { During snow } \\
\text { events }\end{array}$ & $\begin{array}{l}\text { In situ irradiance at ice- } \\
\text { water interface: from } 105 \\
\text { to } 53 \mu \mathrm{mol} \mathrm{m}{ }^{-2} \mathrm{~s}^{-1}\end{array}$ & $6 \mathrm{~h}$ & No & $\begin{array}{l}\text { Yes: DTT } \\
\text { and } \\
\text { lincomycin }\end{array}$ \\
\hline 3 & Thin and thick & $\begin{array}{l}\text { To assess the photoprotective capability of } \\
\text { bottom ice algae when they are exposed to a } \\
\text { sudden increase of irradiance }\end{array}$ & $\begin{array}{l}\text { Before snow } \\
\text { events }\end{array}$ & $\begin{array}{l}\text { In situ irradiance at water } \\
\text { surface }\end{array}$ & $3 \mathrm{~h}$ & No & No \\
\hline
\end{tabular}


Table 2. Photosynthetic properties in bottom ice algae acclimated to thin or thick snow cover before and during the snow events. Values are means $( \pm \mathrm{SD})$ calculated from $\mathrm{n}$ samples of the lightuse efficiency for low irradiances $(\alpha)$, the relative maximum electron transport rate $\left(\mathrm{rETR}_{\max }\right)$ and the light saturation coefficient $\left(E_{k}\right)$

\begin{tabular}{|c|c|c|c|c|}
\hline \multirow[b]{2}{*}{ Photosynthetic parameter } & \multicolumn{2}{|c|}{ Before snow events } & \multicolumn{2}{|c|}{ During snow events } \\
\hline & Thin snow & Thick snow & Thin snow & Thick snow \\
\hline$\alpha\left(\mu \mathrm{mol} \mathrm{m}{ }^{-2} \mathrm{~s}^{-1}\right)^{-1}$ & $\begin{array}{c}0.21 \pm 0.04 \\
(\mathrm{n}=7)\end{array}$ & $\begin{array}{c}0.25 \pm 0.11 \\
(\mathrm{n}=6)\end{array}$ & $\begin{array}{c}0.27 \pm 0.05 \\
(\mathrm{n}=16)\end{array}$ & $\begin{array}{c}0.28 \pm 0.09 \\
(\mathrm{n}=22)\end{array}$ \\
\hline rETR $_{\max }$ (no units) & $\begin{array}{c}7.84 \pm 1.61 \\
(\mathrm{n}=7)\end{array}$ & $\begin{array}{c}3.46 \pm 0.75 \\
(\mathrm{n}=7)\end{array}$ & $\begin{array}{c}7.27 \pm 6.08 \\
(\mathrm{n}=18)\end{array}$ & $\begin{array}{c}7.30 \pm 4.63 \\
(\mathrm{n}=22)\end{array}$ \\
\hline$E_{k}\left(\mu \mathrm{mol} \mathrm{m}{ }^{-2} \mathrm{~s}^{-1}\right)$ & $\begin{array}{c}45.8 \pm 8.5 \\
(\mathrm{n}=6)\end{array}$ & $\begin{aligned} 22.2 & \pm 11.2 \\
(\mathrm{n} & =5)\end{aligned}$ & $\begin{array}{c}26.5 \pm 15.9 \\
(\mathrm{n}=17)\end{array}$ & $\begin{array}{c}29.9 \pm 13.1 \\
(\mathrm{n}=21)\end{array}$ \\
\hline
\end{tabular}

Fig. 1. Ice camp location (black dot) near Broughton Island $\left(67^{\circ} 28^{\prime} \mathrm{N}, 63^{\circ} 47^{\prime} \mathrm{W}\right)$. The hamlet of Qikiqtarjuaq is also indicated

Fig. 2. Time series of (a) thin and thick site-averaged snow depth, (b) site-averaged sea ice thickness, (c) nitrate plus nitrite ( $\mathrm{NOx}$ ) concentration and (d) photosynthetically active radiation $\left(E_{\mathrm{PAR}}\right)$ transmittance at the ice-water interface during the 3 sampling periods (before and during snow events, and snowmelt). Average was calculated on 9 to 11 values for (a) and (b), and on 2 to 8 values for $(\mathrm{d})$; bars are \pm SD

Fig. 3. Time series of (a) total chlorophyll $a$ (Tchl $a$ ) concentration, (b) the ratio of photoprotective (PPC) to photosynthetic carotenoids (PSC) and (c) the ratio of the sum of diadinoxanthin and diatoxanthin (DD+DT) to Tchl $a$ under thin and thick snow cover sites during the 3 sampling periods (before and during snow events, and snowmelt). No sampling at thin snow site was performed after 24 June

Fig. 4. Site-averaged relative contribution of major algal groups to chl $a$ concentrations (CHEMTAX analysis) under (a) thin and (b) thick snow covers during the 3 sampling periods (before and during snow events and snowmelt). Average was calculated for each snow cover from 
8 and 12 samples before and during snow events, respectively. During snowmelt, the average was calculated from 5 samples for thin snow and 9 samples for thick snow

Fig. 5. Maximum quantum yield of PSII photochemistry $\left(F_{\mathrm{v}} / F_{\mathrm{m}}\right)$ of bottom ice algae exposed to 10 , 50, 100 and $200 \mu \mathrm{mol}$ photons $\mathrm{m}^{-2} \mathrm{~s}^{-1}$. Bottom ice algae were collected under (a,c) thin and $(\mathrm{b}, \mathrm{d})$ thick snow cover sites $(\mathrm{a}, \mathrm{b})$ before and $(\mathrm{c}, \mathrm{d})$ during snow events. Samples were exposed to the different light conditions for $3 \mathrm{~h}$, followed by $2 \mathrm{~h}$ of recovery at low light $\left(<5 \mu \mathrm{mol}\right.$ photons $\mathrm{m}^{-2}$ $\left.\mathrm{s}^{-1}\right)$. Values are mean \pm SD of experiments performed on (a) 14 May $(\mathrm{n}=3)$, (b) 6 and 12 May $(\mathrm{n}=$ 6), (c) 25 and 29 May $(\mathrm{n}=6)$ and (d) 27 and 31 May $(\mathrm{n}=6)$

Fig. 6. De-epoxidation state index $(\mathrm{DES}=\mathrm{DT} /[\mathrm{DD}+\mathrm{DT}]$, where DT is diatoxanthin and DD is diadinoxanthin) for bottom ice algae exposed to $10,50,100$ and $200 \mu \mathrm{mol}$ photons $\mathrm{m}^{-2} \mathrm{~s}^{-1}$. Bottom sea ice algae were collected under $(\mathrm{a}, \mathrm{c})$ thin and $(\mathrm{b}, \mathrm{d})$ thick snow cover sites $(\mathrm{a}, \mathrm{b})$ before and $(\mathrm{c}, \mathrm{d})$ during snow events, respectively. Samples were exposed to different light conditions for $3 \mathrm{~h}$, followed by $2 \mathrm{~h}$ of recovery at low light $\left(<5 \mu \mathrm{mol}\right.$ photons $\left.\mathrm{m}^{-2} \mathrm{~s}^{-1}\right)$. Values are averages $\pm \mathrm{SD}$ of experiments performed on (a) 14 May (n=3), (b) 6 and 12 May $(n=6)$, (c) 25 and 29 May (n=6) and (d) 27 and 31 May $(n=6)$. Asterisks indicate a significant difference with $T_{0}$ of the respective light treatment: ${ }^{*} \mathrm{p}<0.05 ; * * \mathrm{p}<0.01 ; * * * \mathrm{p}<0.001$

Fig. 7. Variation in (a) estimated photosynthetic active radiation $\left(E_{\mathrm{PAR}}\right)$ at the ice-water interface, (b) $F_{\mathrm{v}} / F_{\mathrm{m}}$ and (c) DES(see Fig. 6) of bottom ice algae in the presence or absence of the inhibitor of DD de-epoxidation (DTT) and of D1 protein synthesis (lincomycin). Duplicate samples of bottom ice algae were collected under thin snow cover site and exposed to in situ irradiance at the icewater interface from 11:00 to 17:00 h (local time, UTC - 05:00) on 21 May

Fig. 8. Variations in (a) incident PAR, (b) $F_{\mathrm{v}} / F_{\mathrm{m}}$, (c) total chlorophyll $a(\mathrm{Tchl} a$ ) and (d) deepoxidation state index $(\mathrm{DES}=\mathrm{DT} /[\mathrm{DD}+\mathrm{DT}]$, where DT is diatoxanthin and DD is diadinoxanthin) for bottom ice algae exposed to incident irradiance from 12:15 to 15:15 h (local time, UTC - 05:00) on 3 May 2015. EPAR data were not recorded between 14:44 and 15:27 h. Bottom ice algae were collected under thin and thick snow cover sites. In (b-d), values are mean $( \pm \mathrm{SD})$ calculated from duplicate samples. DES is missing for the thick snow cover site at 15:15 $\mathrm{h}$ 
Table 1.

\begin{tabular}{|c|c|c|c|c|c|c|c|}
\hline Experiment & Snow cover & Objective & Period & Light source & $\begin{array}{c}\text { Light } \\
\text { exposure }\end{array}$ & Recovery period & $\begin{array}{l}\text { Inhibitor } \\
\text { treatment }\end{array}$ \\
\hline 1 & $\begin{array}{l}\text { Thin and } \\
\text { thick }\end{array}$ & $\begin{array}{l}\text { To assess the short-term effect of } \\
\text { irradiance range observed at the ice- } \\
\text { water interface on the photophysiological } \\
\text { response of bottom ice algae }\end{array}$ & $\begin{array}{l}\text { Before and } \\
\text { during } \\
\text { snow } \\
\text { events }\end{array}$ & $\begin{array}{l}\text { Cool white light- } \\
\text { emitting diodes: } \\
10,50,100, \\
200 \mu \mathrm{mol} \mathrm{m}^{-2} \mathrm{~s}^{-1}\end{array}$ & $3 \mathrm{~h}$ & $\begin{array}{l}\text { Yes, } 2 \mathrm{~h}, \\
<5 \mu \mathrm{mol} \mathrm{m}^{-2} \mathrm{~s}^{-1}\end{array}$ & No \\
\hline 2 & Thin & $\begin{array}{l}\text { To determine the respective importance } \\
\text { of DES and of the synthesis of PSII D1 } \\
\text { protein to support bottom ice algae in } \\
\text { maintaining their photochemical } \\
\text { performance when exposed to their } \\
\text { natural light environment }\end{array}$ & $\begin{array}{l}\text { During } \\
\text { snow } \\
\text { events }\end{array}$ & $\begin{array}{l}\text { In situ irradiance at ice- } \\
\text { water interface: from } \\
105 \text { to } 53 \mu \mathrm{mol} \mathrm{m}{ }^{-2} \mathrm{~s}^{-1}\end{array}$ & $6 \mathrm{~h}$ & No & $\begin{array}{l}\text { Yes: } \\
\text { DTT and } \\
\text { lincomycin }\end{array}$ \\
\hline 3 & $\begin{array}{l}\text { Thin and } \\
\text { thick }\end{array}$ & $\begin{array}{l}\text { To assess the photoprotective capability } \\
\text { of bottom ice algae when they are } \\
\text { exposed to a sudden increase of } \\
\text { irradiance }\end{array}$ & $\begin{array}{l}\text { Before } \\
\text { snow } \\
\text { events }\end{array}$ & $\begin{array}{l}\text { In situ irradiance at } \\
\text { water surface }\end{array}$ & $3 \mathrm{~h}$ & No & No \\
\hline
\end{tabular}

Table 2.

\begin{tabular}{lll|ll}
\hline \multicolumn{2}{c|}{ Before snow events } & \multicolumn{2}{c}{ During snow events } \\
\hline $\begin{array}{l}\text { Photosynthetic } \\
\text { parameter }\end{array}$ & \multicolumn{1}{c|}{ Thin snow } & \multicolumn{1}{c}{ Thick snow } & \multicolumn{1}{c}{ Thin snow } & Thick snow \\
\hline$\alpha\left(\mu \text { mol m}^{-2} \mathrm{~s}^{-1}\right)^{-1}$ & $\begin{array}{l}0.21 \pm 0.04 \\
(\mathrm{n}=7)\end{array}$ & $\begin{array}{l}0.25 \pm 0.11 \\
(\mathrm{n}=6)\end{array}$ & $\begin{array}{l}0.27 \pm 0.05 \\
(\mathrm{n}=16)\end{array}$ & $\begin{array}{l}0.28 \pm 0.09 \\
(\mathrm{n}=22)\end{array}$ \\
\hline rETR $_{\max }$ (no unit) & $\begin{array}{l}7.84 \pm 1.61 \\
(\mathrm{n}=7)\end{array}$ & $\begin{array}{l}3.46 \pm 0.75 \\
(\mathrm{n}=7)\end{array}$ & $\begin{array}{l}7.27 \pm 6.08 \\
(\mathrm{n}=18)\end{array}$ & $\begin{array}{l}7.30 \pm 4.63 \\
(\mathrm{n}=22)\end{array}$ \\
\hline $\mathrm{E}_{\mathrm{k}}\left(\mu \mathrm{mol} \mathrm{m}^{-2} \mathrm{~s}^{-1}\right)$ & $\begin{array}{l}45.8 \pm 8.5 \\
(\mathrm{n}=6)\end{array}$ & $\begin{array}{l}22.2 \pm 11.2 \\
(\mathrm{n}=5)\end{array}$ & $\begin{array}{l}26.5 \pm 15.9 \\
(\mathrm{n}=17)\end{array}$ & $\begin{array}{l}29.9 \pm 13.1 \\
(\mathrm{n}=21)\end{array}$ \\
\hline
\end{tabular}




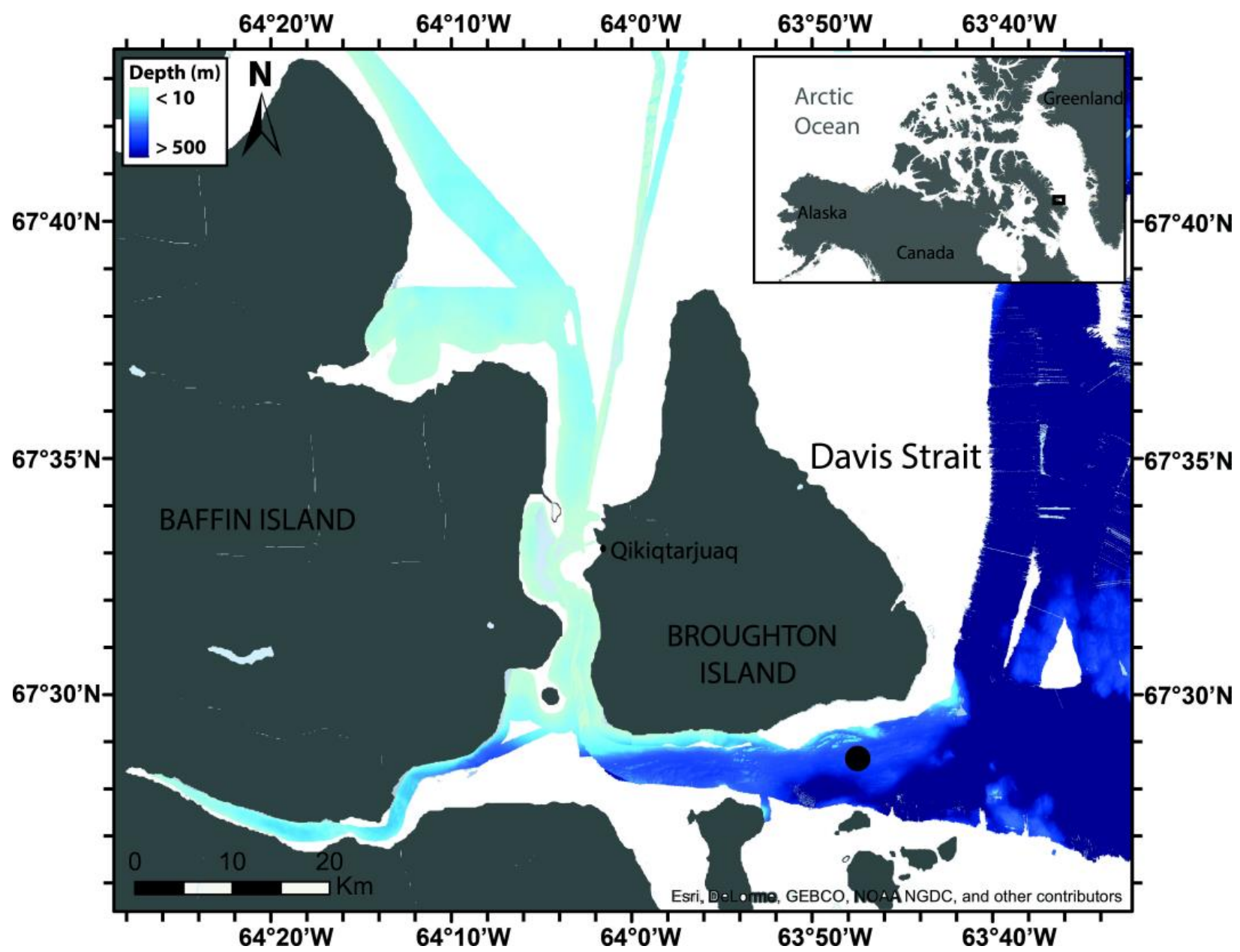

Figure 1. 

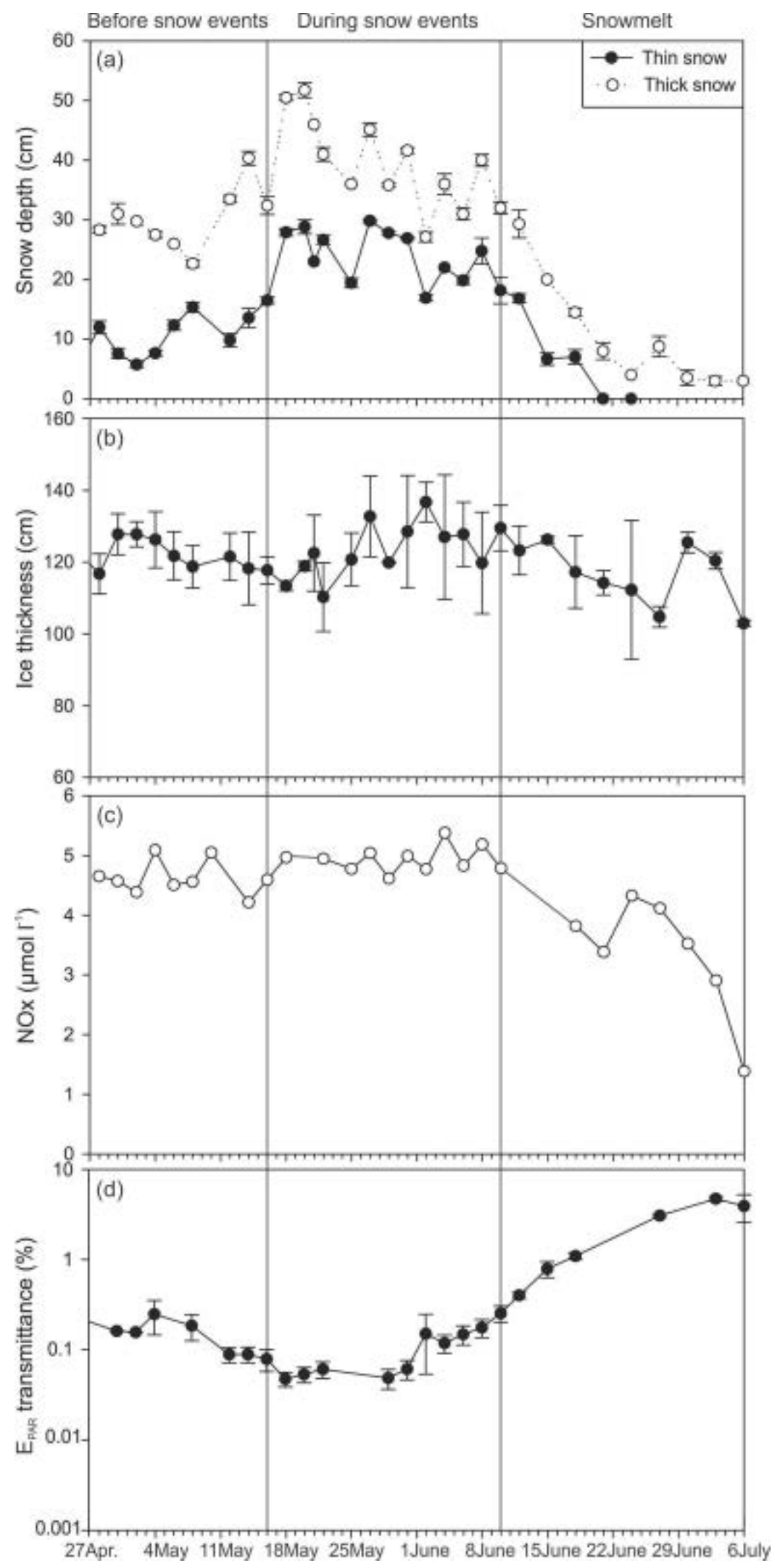

Figure 2 . 

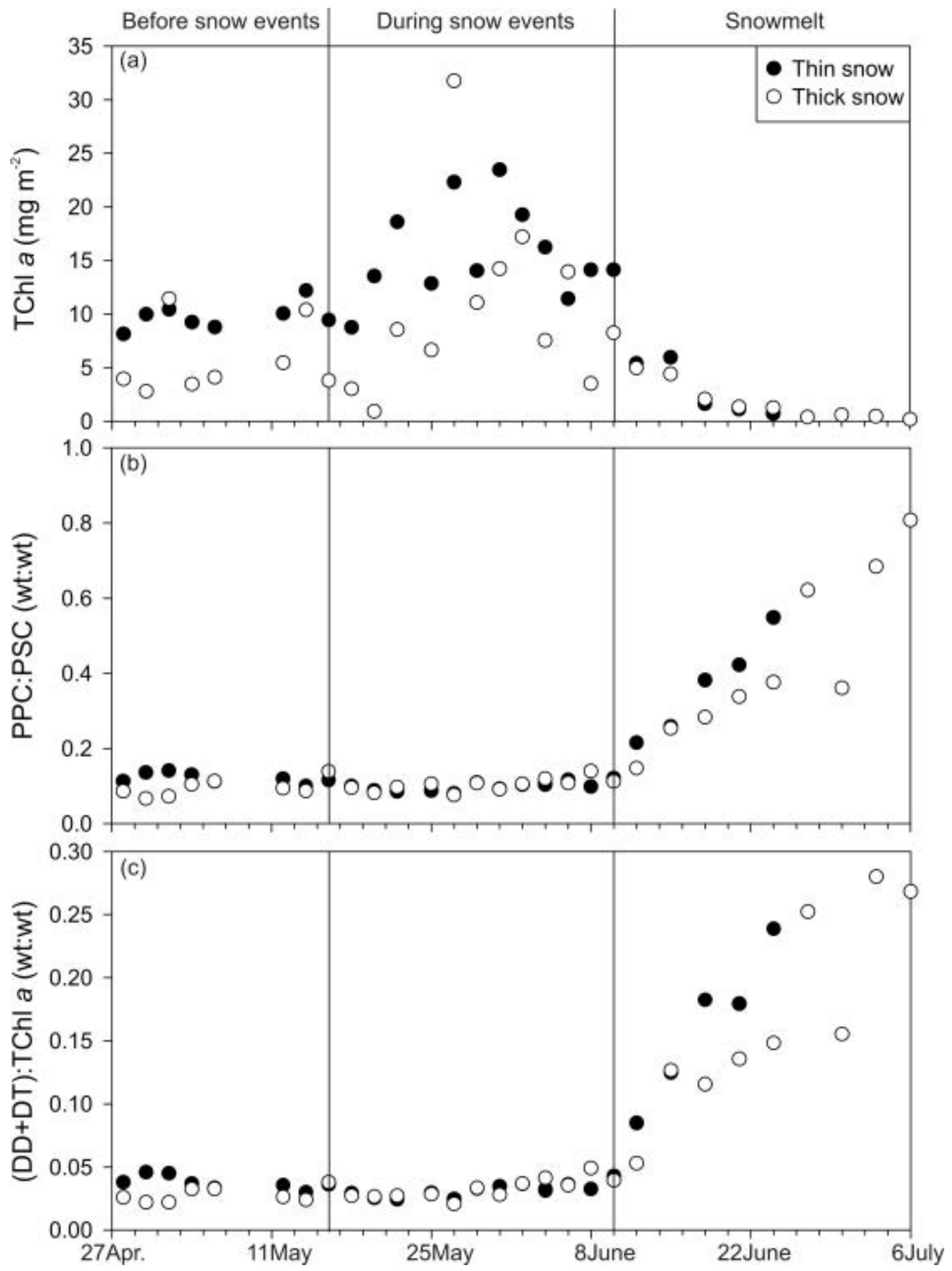

Figure 3. 

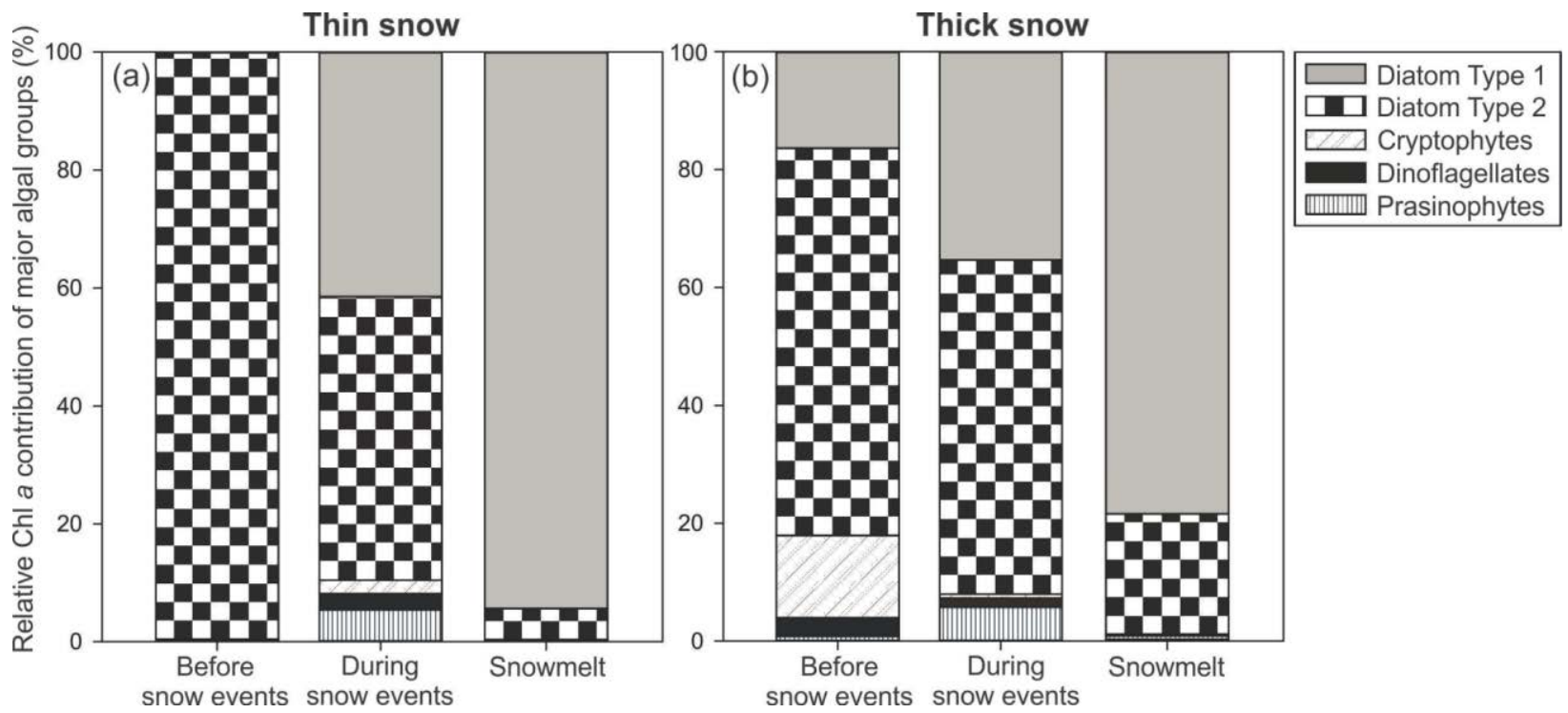

Figure 4. 

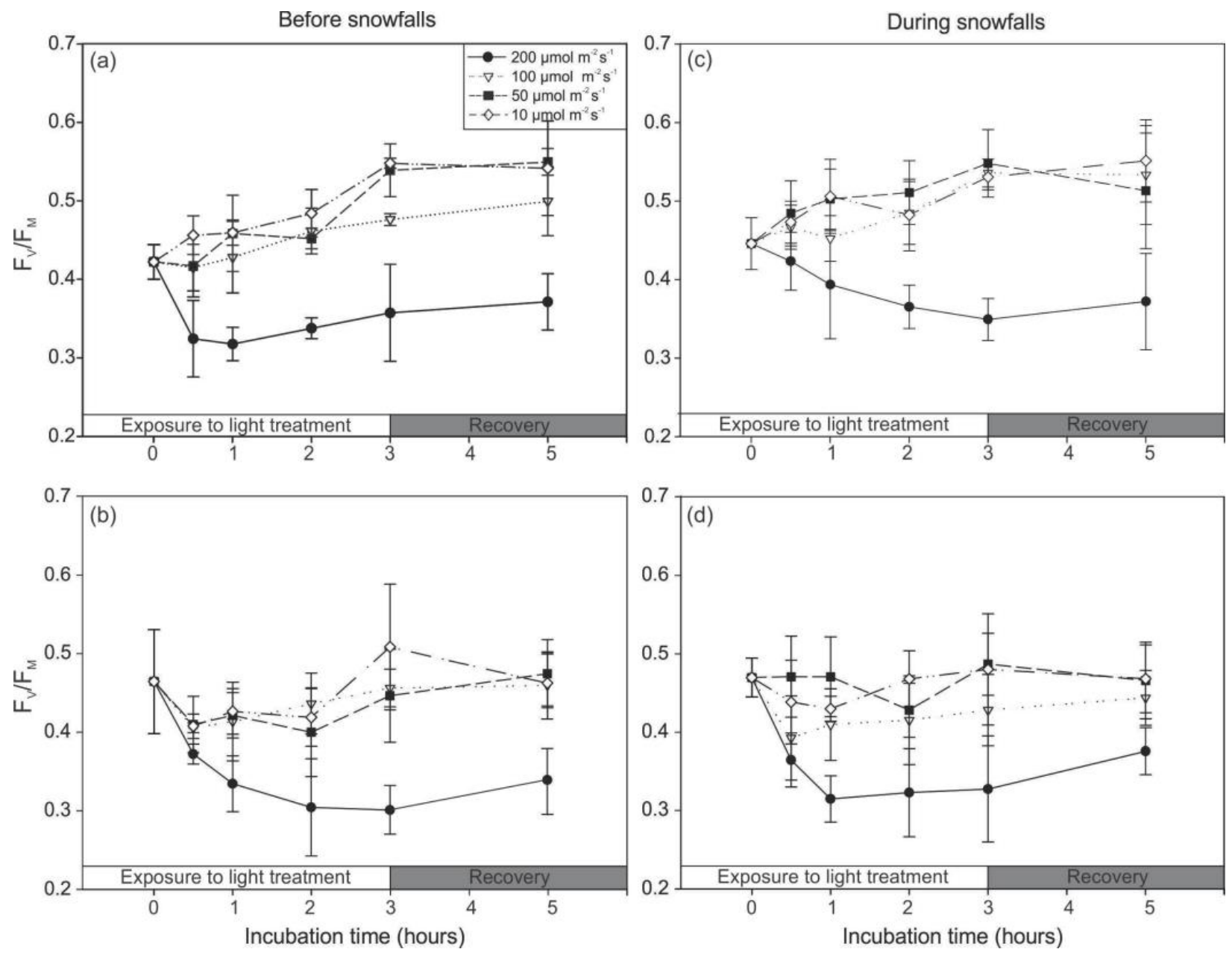

Figure 5 

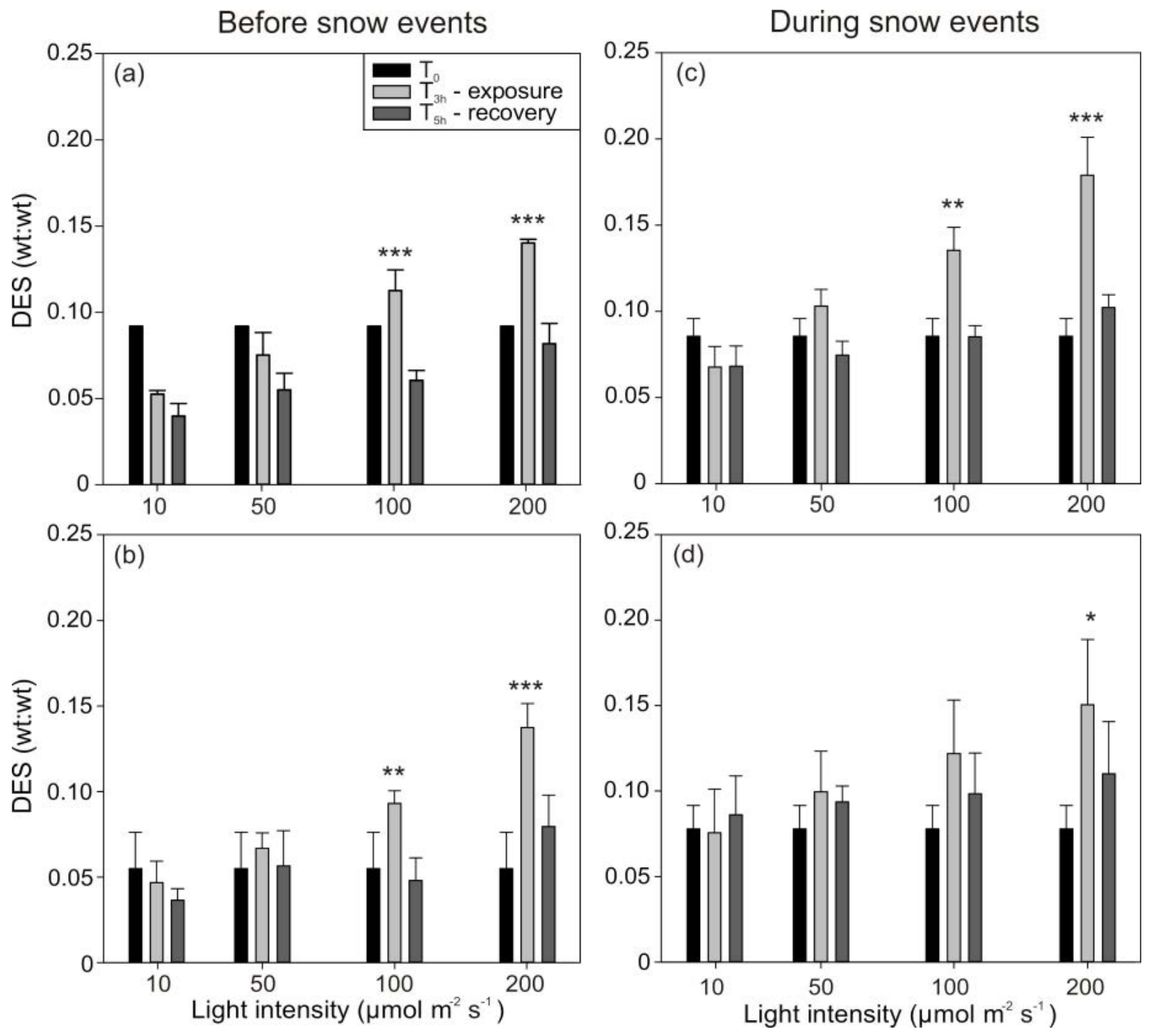

Figure 6. 

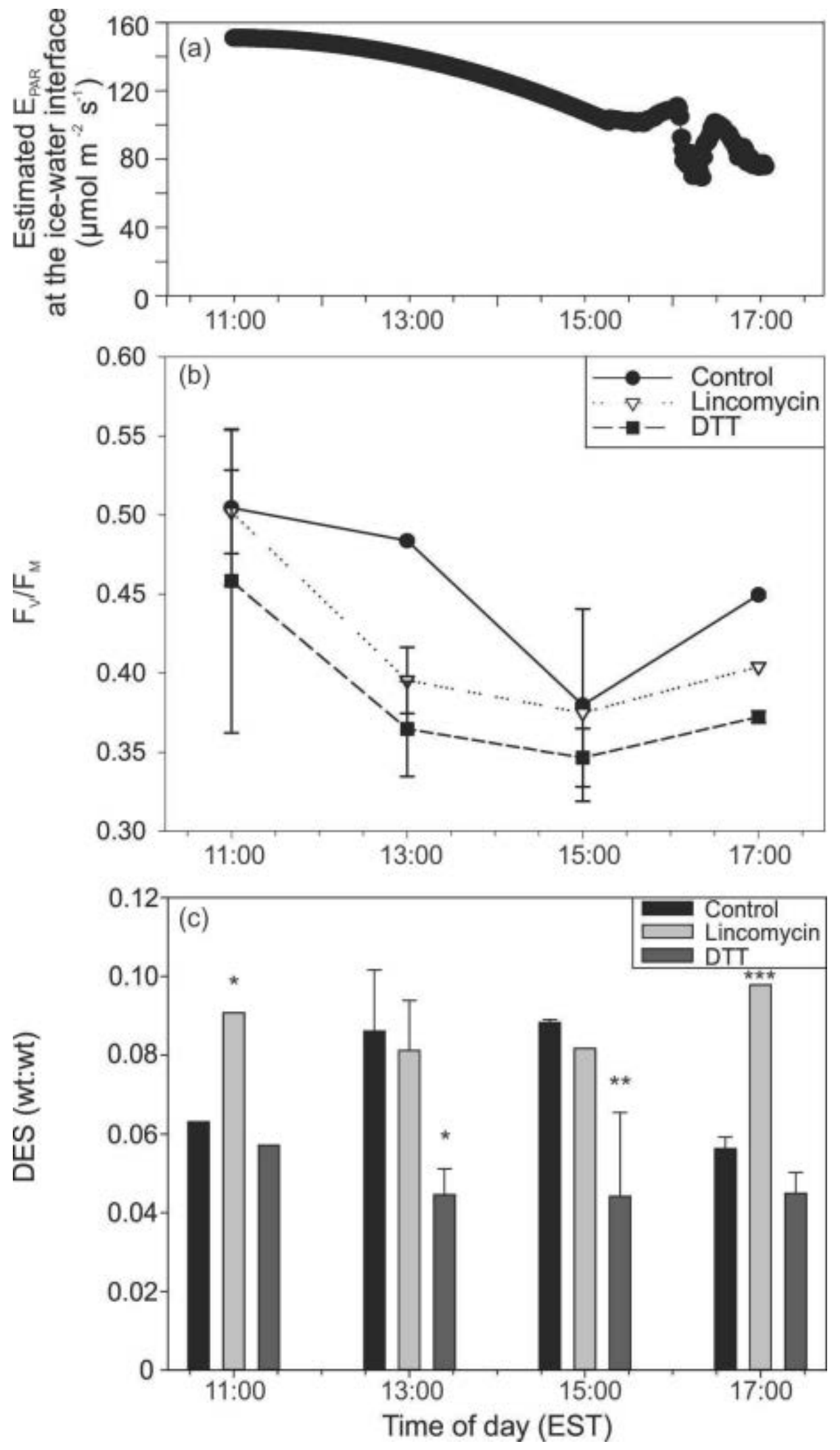

Figure 7. 
3 May 2015
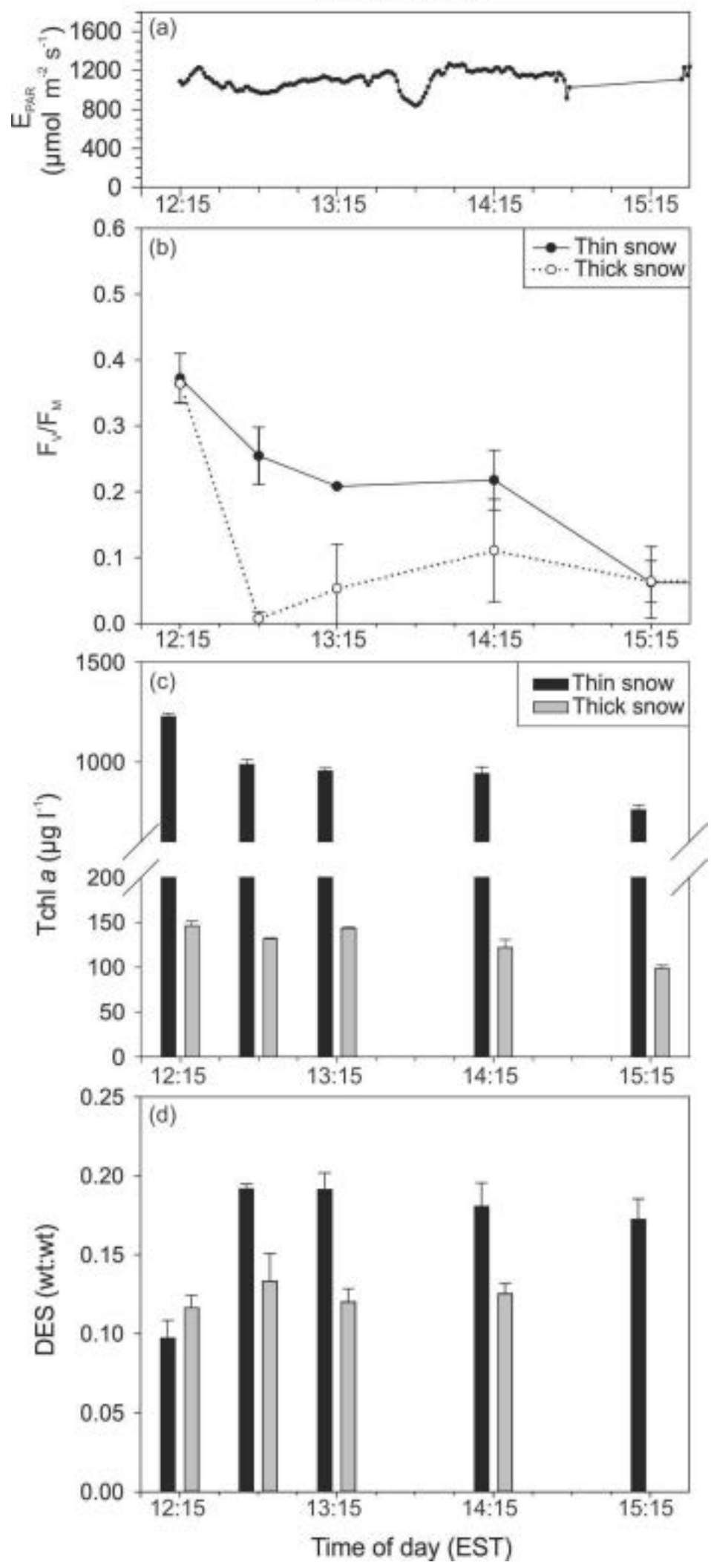

Figure 8 